\title{
Host genetic factors associated with hepatitis B virus infection and progression to chronic disease: A systematic review and Meta analysis
}

Hussein Mukasa Kafeero ( $\square$ husseinmukasakafeero@gmail.com )

Islamic University in Uganda https://orcid.org/0000-0002-9418-2831

Dorothy Ndagire Ndagire

Makerere University College of Natural Scienecs

Hasifah Nanyingi Nanyingi

Islamic University in Uganda

Hakim Sendagire Sendagire

Makerere University College of Health Sciences

Research article

Keywords: SNPs, Cytokine, promoter genes, meta-analysis, VDR

Posted Date: July 31st, 2019

DOI: https://doi.org/10.21203/rs.2.12164/v1

License: (c) (i) This work is licensed under a Creative Commons Attribution 4.0 International License.

Read Full License 


\section{Abstract}

Abstract Back ground Contradicting results from many laboratories on the role of genetic factors in the susceptibility/resistance to hepatitis B infection have been reported. In this review we examined 27 published full research articles and assessed the role of Th1/Th2 cytokine promoter and vitamin D receptor gene polymorphisms. We summarized the available data on the relationship between the gene polymorphisms and susceptibility/resistance to hepatitis B virus infection together with likely disease evolution to come up with candidate single nucleotide polymorphisms implicated in the disease state with the population. Method The study was done in tandem with the PRISMA standards and the Cochran's Q test, 12 statistics for heterogeneity and the Odds ratio were calculated using a commercially available soft ware called MedCalcs (http://www.medcalc.org). A random effects model was used to pool the odds ratio for heterogeneities $\geq 50 \%$ or else a fixed effects model was used. All analyses were done at 95\% Confidence Interval and a $\mathrm{P}<0.05$ was considered statistically significant. Results We found that IL10-592C/A genotype AA ( $P=0.017,0 R=0.752,95 \% C l=0.595$ to 0.950$)$ and TNF-a-238G/A genotype AA+ $A G(P<0.001, O R=0.407,95 \% \mathrm{Cl}=0.005$ to 30.1$)$ were significantly associated with reduced risk of hepatitis $B$ infection by the random effects model. TNF-a-238G/A genotype GG had the risk of chronic infection (OR=3.587, $95 \% \mathrm{Cl}=0.127$ to 101.176) under the random effect model. Most of the other SNPs had borderline risk of $\mathrm{HBV}$ infection (OR 0.6 to 1.12) with a few cases of high risk, IL-10-1082A/G genotype AA $(\mathrm{OR}=1.608,95 \% \mathrm{Cl}=0.861$ to 3.003$)$ and reduced risk, IL-10-1082A/G genotype $A G(O R=0.485,95 \%$ $\mathrm{Cl}=0.232$ to 1.014 ) Conclusion We found that IL-10-592C/A genotype AA and TNF-a-238G/A genotype $A A+A G$ were significantly associated with reduced risk of hepatitis $B$ infection.

\section{Introduction}

The pattern and clinical manifestation of hepatitis $B$ infection is variable and a genetic component is highly implicated in susceptibility and evolution of the disease. However results from many laboratories have reported with contradictions and concordances on which alleles are involved in disease severity and evolution from chronic infection, through acute disease, inactive carrier state, self-limiting to liver cirrhosis and hepatocellular carcinoma(F. Wang, 2003). The available data suggests that understanding human genetic factors will provide constructive clues on the disparity in the evolution of the disease among different populations. The recently completed human genome project (HGP) reported 35,000 genes whose alleles are highly polymorphic with single nucleotide polymorphisms (SNPs) in the gene itself, the franking regions or the promoter region (F. Wang, 2003). There are an estimated number of 3.5 million SNPs in our genome implicated in the population and individual differences that manifest in HBV susceptibility and evolution (F. Wang, 2003). These polymorphisms in promoter region of a particular gene will affect the expression levels of the genes resulting into protective effect (HBV resistant alleles) or increased prone to infection (HBV susceptibility). Establishing the gene loci that are responsible for the disease outcome in HBV infection requires knowledge of the function of the gene and its role in the host response to HBV infection (Q. Gao et al., 2017). One plausible alternative is assaying the immunological responses by looking at the levels of cytokines during HBV infection. Several Th1 cytokines (TNF- $a$ and 
INF-y) participate in viral clearance while Th2 cytokine like IL-10 are potent inhibitors of Th1 effector cells (Sofian et al., 2013). In addition Vitamin D is involved in the immune modulation between Th1 and Th2 cytokines by inhibiting the Th1 responses and activating Th2 responses (F. Wang, 2003). Thus discussing the effect of SNPs in the Th1/Th2 cytokine promoter genes in the susceptibility to HBV infection and disease profile in isolation without paying attention to the polymorphisms in the VDR gene will give inconclusive arguments.

Tumor Necrosis Factor alpha (TNF-a) gene has five single nucleotide polymorphisms in the promoter region located at the following positions upstream of the transcription initiation site; $-238 \mathrm{G} / \mathrm{A},-308 \mathrm{G} / \mathrm{A}$, $-857 \mathrm{C} / \mathrm{T},-863 \mathrm{C} / \mathrm{A}$ and $-1031 \mathrm{~T} / \mathrm{C}$ (Gusatti et al., 2016). However in our meta-analysis and systematic review, we investigated the relationship between $-238 \mathrm{G} / \mathrm{A}$ and $-308 \mathrm{G} / \mathrm{A}$ polymorphisms and the susceptibility to HBV infection as well as the disease profile in chronically infected patients. Interleukin 10 (IL-10) gene has three single nucleotide polymorphisms in the promoter region located at $-1082 \mathrm{~A} / \mathrm{G},-$ 819T/C and -592A/C upstream of the transcription initiation site(F. Wang, 2003, Dondeti, El-maadawy, \& Talaat, 2016). Polymorphisms in the IL-10 promoter gene will affect its expression and being a potent inhibitor of Th1 cytokines, the expression of Th1 cytokines will be affected.

The aim of this study was to evaluate the role of the polymorphisms in the cytokine promoter genes and vitamin $D$ receptor in the individual and population based differences to infection with hepatitis $B$ virus. Understanding the polymorphisms within the promoter genes of the Th1/Th2 cytokines as well as in the vitamin $\mathrm{D}$ receptor genes, a hormone that modulates the activities of Th1 and Th2 cytokines with illuminate on the individual/population based differences in the susceptibility to hepatitis B infection.

\section{Materials And Methods}

\section{Journal article search strategy}

This study was done in tandem with the PRISMA standards (see details of PRISMA checklist). The effect of host genetic factors particularly Single Nucleotide Polymorphisms (SNPs) in selected Th1/Th2 cytokine genes and Vitamin D Receptor (VDR) polymorphisms on the chronicity of hepatitis B infection and clinical profiles of the diseases were identified by thorough searches in the following data bases; Biomed central, PubMed, and Google scholar up to December, 2017. The following terms were used during the search: "Th1 cytokines", "Th2 cytokines", "promoter gene polymorphisms", "IL-10", "TNF-a" "IFN- $\gamma$ " "VDR" or "Vitamin D Receptor"," genotype" and "HBV or hepatitis B". The search results yielded over 700 journal articles.

\section{Selection of articles for meta-analysis}

The articles obtained were evaluated by three independent reviewers (HMK, HN and DN) for them to be either excluded or included in the study. The papers included in the study were selected after meeting the 
following preconditions; must have been a case-control or cohort study, assessing the polymorphisms in the VDR gene, IL-10, TNF- $a$ or INF-y gene promoter and HBV clinical outcome, and the distribution of the genotypes in the healthy controls within the population were in conformity to Hardy-Weinberg equilibrium

Articles excluded from the study included those with insufficient data, not investigating cytokines, investigating haplotypes or review/meta-analyses.

\section{Extracting data from the journal articles}

Two of the authors (HMK and $\mathrm{HN}$ ) designed a protocol for the selection criteria aforementioned above. Both reviewers extracted data independently and entered the data in the spread sheet pending its analysis. The two authors compared their records after the review of the journal articles and any differences in the records was resolved following a consensus in their meetings. In our meta-analysis, the following characteristics were recorded for each study; first author, year of publication, country/ethnicity, genotyping method, definition of a case/control, gene locus investigated and number of cases/controls.

\section{Quality assessment}

The quality of each study was assessed by two independent reviewers (HMK and HN) and the NewcastleOttawa scale was used (Stang, 2010). The third and fourth authors (HS and DN) supervised the work of the HMK and $\mathrm{HN}$ to ensure consistence in the quality of the work assessed. Three dimensions of comparability, selection and exposure were considered as described in the Newcastle-Ottawa scale. Studies were assigned scores ranging from the worst of zero to the best of 9 . Any study with a score $\geq 7$ was declared a high quality study.

\section{Data analysis}

Cochran's $Q$ test and $I^{2}$ statistics were performed using the commercially available software (http://www.medcalc.org) to evaluate the extent of heterogeneity of all the eligible studies for metaanalysis (Zintzaras \& JP, 2005). For studies with $P_{\text {het }}$ Value greater than 0.1 , there was no heterogeneity among the pooled studies (Zintzaras \& JP, 2005). In effect, the fixed effects model was used in the absence of the heterogeneity. Or else, the random effect model was used (Zintzaras \& JP, 2005) The odds ratios for each study and $95 \% \mathrm{Cl}$ were calculated to determine the association of the polymorphisms in the promoter genes of Th1/Th2 cytokines and the VDR with chronicity and clinical outcome of the disease. The pooled odds ratios were determined and a $p<0.05$ was considered statistically significant and the publication bias was assessed by carrying out a funnel plot. All analyses were performed using the a statistical software called MedCalc available on http://www.medcalc.org

\section{Results}




\section{Studies included in the meta-analysis and their characteristics}

The screening of the eligible studies was done the PRISMA strategy (Figure 1). In total, 27 articles with a total of 6,181 cases and 4,540 controls. The characteristics of each study were presented in Table 1. In our study, 12 eligible studies involved IL-10-1082A/G and IL-10-592C/A polymorphisms (Dondeti, Elmaadawy, \& Talaat, 2016, Heidari, Moudi, Sagheb, \& Moudi, 2016, Gao et al., 2016,Gusatti et al., 2016, Yao et al., 2015, Manjita et al., 2014, Sofian et al., 2013Ge et al., 2009, Baghi, Alavian, Mehrnoush, \& Salimi, 2015, Q. Gao et al., 2017) Sofian et al., 2013), 8 eligible studies involved INF- $\gamma+874$ (Heidari et al., 2016, Yao et al., 2015, Migita et al., 2005, Ognjanovic, Yuan, Chaptman, Fan, \& Yu, 2009), 9 studies involved TNF-a (Panigrahi et al., 2014, Gusatti et al., 2016, Panigrahi et al., 2014, Migita et al., 2005, Q. Gao et al., 2017, Ognjanovic et al., 2009, Kim et al., 2018, Heidari et al., 2016, Fletcher et al., 2011) and 5 studies involved VDR (Falleti et al., 2010,Suneetha et al., 2006, Peng et al., 2014, Elmer, Tuncbilek, Aydin, \& Hizel, 2013, X. Yao et al., 2013). The numbers of quality scores for each study for each study were summarized in Table 1.

Fig.1: Flow chart for study eligibility following PRISMA criterion

In total, 27 full research articles were used in our meta-analysis. The characteristics of the studies are indicated in table 1 below.

Table 1: Characteristics of eligible studies for meta-analysis

Table 2: General results of the meta-analysis on the cytokine/VDR gene polymorphisms and clinical outcome of HBV infection

Figure 2: Dominant models IL-10-592 AA on the risk of HBV $-\mathrm{HC}$. The association was indicated as odds ratio (OR) with corresponding $95 \%$ confidence interval. The OR estimate of each study is indicated by the solid black square. The size of the square represents the weight contributed by each study in the meta-analysis. The pooled Odds ratio for both fixed effects and random effects is shown by the diamonds. OR more than 1 indicates increased risk or susceptibility to HBV infection

The results show that IL-10-592AA genotype when compared between $\mathrm{CHB}$ infected patients and healthy controls, was significantly associated with decreased risk of HBV infection under the Random effect model $(P=0.017, \mathrm{OR}=0.752,95 \% \mathrm{Cl}=0.595$ to 0.950 , Figure 2, Table 2). On the other hand, the prevalence of the genotype $A A+A C$ between the health controls and the $\mathrm{CHB}$ patients, it was shown to have a decreased risk of CHB though the findings were not statistically significant $(P=0.303, O R=0.787$, $95 \% \mathrm{Cl}=0.505$ to 1.228 , Figure 3 , Table 2 ).

Figure 3: Dominant model IL-10-592 AA+AC on the risk of CHB when compared with health controls. The association was indicated as odds ratio (OR) with corresponding $95 \%$ confidence interval. The OR estimate of each study is indicated by the solid black square. The size of the square represents the weight 
contributed by each study in the meta-analysis. The pooled Odds ratio for both fixed effects and random effects is shown by the diamonds. OR more than 1 indicates increased risk or susceptibility to HBV infection

Additionally, we observed a statistically significant association between the IL-10-592AA genotype with resolving HBV infection in the fixed effects model $(P=0.039, \mathrm{OR}=0.602,95 \% \mathrm{Cl}=0.372$ to 0.974 , Figure 3 , Table 2). Further analysis of the IL $-10592 A A+A C$ genotype among the chronically infected patients and the asymptomatic carriers (ASC) was associated with decreased risk under the fixed effects model (P $=0.103, \mathrm{OR}=0.705,95 \% \mathrm{Cl}=0.463$ to 1.073 , Figure 4 , Table 2 ).

Figure 4 Dominant model IL-10-592 AA on the risk of HBV - self resolved. The association was indicated as odds ratio (OR) with corresponding 95\% confidence interval. The OR estimate of each study is indicated by the solid black square. The size of the square represents the weight contributed by each study in the meta-analysis. The pooled Odds ratio for both fixed effects and random effects is shown by the diamonds. OR more than 1 indicates increased risk or susceptibility to HBV infection

Figure 5 Dominant model IL-10-592 AA +AC on the risk of HBV - ASC. The association was indicated as odds ratio (OR) with corresponding $95 \%$ confidence interval. The OR estimate of each study is indicated by the solid black square. The size of the square represents the weight contributed by each study in the meta-analysis. The pooled Odds ratio for both fixed effects and random effects is shown by the diamonds. OR more than 1 indicates increased risk or susceptibility to HBV infection

Our meta-analysis also investigated the prevalence of single nucleotide polymorphisms at the IL-101082 genetic loci among the cases and controls. The IL-10-1082 AA, AG and GA+ GG genotypes in the HBV patients and controls showed that AA genotype was associated with increased chances of developing CHB infection while AG + GG combined and AG were associated with decreased risk of infection $(P=0.136, O R=1.61,95 \% \mathrm{Cl}=0.861$ to $3.003, \mathrm{P}=00.054, \mathrm{OR}=0.485,95 \% \mathrm{Cl}=0.232$ to $1.014, \mathrm{P}$ $=0.587, \mathrm{OR}=0.826,95 \% \mathrm{Cl}=0.415$ to 1.644 respectively, Table 2 and Figure 6 )

Figure 6 Dominant model IL-10-1082 AA, AG and AA + AG on the risk of CHB -health controls. The association was indicated as odds ratio (OR) with corresponding $95 \%$ confidence interval. The OR estimate of each study is indicated by the solid black square. The size of the square represents the weight contributed by each study in the meta-analysis. The pooled Odds ratio for both fixed effects and random effects is shown by the diamonds. OR more than 1 indicates increased risk or susceptibility to HBV infection

The IL-10-1082 AA, AG and GA+ GG genotypes in the HBV patients and self limited / resolved showed that AA genotype was associated with increased chances of developing $\mathrm{CHB}$ infection while AG and GA+ GG combined were associated with increased chances of resolving the disease $(P=0.788, O R=1.045$, $95 \% \mathrm{Cl}=0.757$ to $1.442, \mathrm{P}=0.782, \mathrm{OR}=0.932,95 \% \mathrm{Cl}=0.565$ to $1.538, \mathrm{P}=0.788, \mathrm{OR}=0.957,95 \% \mathrm{Cl}=$ 0.693 to 1.320 , Figure 7 , Table 2) 
Figure 7: Dominant model IL-10-1082 AA, AG and AA + AG on the risk of HBV - self resolved. The association was indicated as odds ratio (OR) with corresponding $95 \%$ confidence interval. The OR estimate of each study is indicated by the solid black square. The size of the square represents the weight contributed by each study in the meta-analysis. The pooled Odds ratio for both fixed effects and random effects is shown by the diamonds. OR more than 1 indicates increased risk or susceptibility to HBV infection

\section{Relationship between the polymorphisms in the Tumor necrosis factor alpha (TNF-a-238G/A) and the development of HBV infection}

In the present meta-analysis, the results from the random effects model suggested that the genotypes $A A+G G$ and $G G$ were associated with reduced risk of infection when the prevalence of these genotypes were compared in the health controls and chronic sufferers of the disease $(P=0.733, O R=0.863,95 \% \mathrm{Cl}=$ 0.371 to 2.008 and $P=0.101, R=0.409,95 \% \mathrm{Cl}=0.140$ to 1.18 ) respectively. However the combined genotypes $A A+G G$ had a borderline reduced risk compared to the single genotype GG (Figure 8, Table 2).

Figure 8: Dominant model TNF-a-238 AA+GG and GG on the risk of HBV compared to the Health controls. The association was indicated as odds ratio (OR) with corresponding $95 \%$ confidence interval. The OR estimate of each study is indicated by the solid black square. The size of the square represents the weight contributed by each study in the meta-analysis. The pooled Odds ratio for both fixed effects and random effects is shown by the diamonds. OR more than 1 indicates increased risk or susceptibility to HBV infection

For further assessment, we carried group analysis involving resolved and asymptomatic controls and compared them with chronic carriers of HBV (Figure 9, Table 2). GA+GG and AG were associated with borderline reduced risk of HBV chronicity but increasing cases of HBV resolution $(P<0.001, O R=0.407$, $95 \% \mathrm{Cl}=0.005$ to 30.1 and, $\mathrm{P}=0.453, \mathrm{OR}=3.587,95 \% \mathrm{Cl}=0.127$ to 101.176$)$. The results for the patients with $\mathrm{GA}+\mathrm{GG}$ who had resolved $\mathrm{HBV}$ when compared with the chronically infected patients were statistically significant $(P<0.001)$.

On comparing the patients with chronic HBV infection with the asymptomatic carriers, AA+AG genotypes had borderline reduced risk of chronic infection $(P=0356, O R=0.845,95 \% \mathrm{Cl}=0.591$ to 1.208$)$ under the fixed effects model while $G G$ genotype had increased risk of remaining chronically infected $(P=0.289$, OR $=1.4,95 \% \mathrm{Cl}=0.591$ to 1.208 ) under the random effects model

Figure 9: Dominant model TNF-a-238 AA+GG and GG on the risk of HBV compared to the asymptomatic and self resolved. The association was indicated as odds ratio (OR) with corresponding $95 \%$ confidence interval. The OR estimate of each study is indicated by the solid black square. The size of the square represents the weight contributed by each study in the meta-analysis. The pooled Odds ratio for both 


\section{Relationship between the polymorphisms in the Interferon Gamma (INF- $\mathrm{Y}+874 \mathrm{~A} / \mathrm{T})$ and the development of HBV infection}

In our meta-analysis, we also compared the prevalence of INF- $y+874$ AA+ AT and AA among the chronically infected HBV patients with the health controls to establish the association of these genotype to the susceptibility/resistance to HBV infection (Table 2). The pooled odds ratios for genotype AA showed a border line reduced risk of HBV infections by the random model $(P=0.944, O R=0.976,95 \% \mathrm{Cl}=$ 0.491 to 1.937 ) while the results for the combined genotypes AA+AT reported a much reduced risk of HBV infection when the chronically infected patients were compared with the health controls by random model $(P=0.139, \mathrm{OR}=0.522,95 \% \mathrm{Cl}=0.220$ to 1.235$)$

\section{Relationship between the polymorphisms in the Vitamin D Receptor (VDR A/a \& VDR T/t) genes and the development of HBV infection}

We compared the relative risk of two polymorphisms in the genes of the receptors of vitamin $D$ (VDR A/a and $T / t)$ in the homozygous dominant, heterozygous and homozygous recessive. Our study established that in the homozygous state, $\mathrm{AA}(\mathrm{P}=0.227, \mathrm{OR}=0.792,95 \% \mathrm{Cl}=0.543$ to 1.156$)$ \& aa, $(\mathrm{P}=0.553, \mathrm{OR}=$ $0.831,95 \% \mathrm{Cl}=0.452$ to 1,529$)$ there was a reduced risk of infection with HBV. However, in the heterozygous state, $\mathrm{Aa}(\mathrm{P}=0.628, \mathrm{OR}=1.059,95 \% \mathrm{Cl}=0.840$ to 1.33$)$ revealing a borderline increased risk. (Figure 10, Table 2)

Figure 10: Dominant and recessive model of VDR A/a, genotypes $A A, A a$ and $a a$ on the risk of HBV compared to the self controls. The association was indicated as odds ratio (OR) with corresponding $95 \%$ confidence interval. The OR estimate of each study is indicated by the solid black square. The size of the square represents the weight contributed by each study in the meta-analysis. The pooled Odds ratio for both fixed effects and random effects is shown by the diamonds. OR more than 1 indicates increased risk or susceptibility to HBV infection

Regarding the VDR T/t gene polymorphism, our meta-analysis established the homozygous genotype TT $(P=0.791, O R=0.776,95 \% \mathrm{Cl}=0.813$ to 1.171$)$ and $\mathrm{tt}(\mathrm{P}=0.832, \mathrm{OR}=0.976,95 \% \mathrm{Cl}=0.779$ to 1.223$)$ were associated with reduced risk of infection with $\mathrm{HBV}$ whereas the heterozygous genotype $\mathrm{Tt}(\mathrm{P}=$ $0.496, \mathrm{OR}=1.06,95 \% \mathrm{Cl}=0.895$ to 1.258 ) was associated with increased risk of chronic infection with HBV (Figure 11, Table 2) 
Figure 11: Dominant and recessive model of VDR T/t, genotypes $T T$, Tt and $t t$ on the risk of HBV compared to the self controls. The association was indicated as odds ratio (OR) with corresponding $95 \%$ confidence interval. The OR estimate of each study is indicated by the solid black square. The size of the square represents the weight contributed by each study in the meta-analysis. The pooled Odds ratio for both fixed effects and random effects is shown by the diamonds. OR more than 1 indicates increased risk or susceptibility to HBV infection

\section{Publication bias}

A Begg's funnel plot was used to investigate publication bias in our meta-analysis. the results showed no significant publication bias was detected with the funnel plot.

Fig: 12 Begg's funnel plot for publication bias

\section{Discussion}

The differences in the susceptibility to HBV infection, disease evolution and clinical outcome at population and individual levels have been implicated on the differences in host genetic factors ( $F$. Wang, 2003)The cytokine genes and their promoter gene polymorphisms remain pivotal in this subject. Cytokines modulate nearly phases of immune response following an infection with HBV. Polymorphisms in their genes and or their promoter will affect their expression levels which in turn compromise their immune modulator role. In addition, vitamin $D$ has been closely linked to immune modulation of Th1/Th2 cytokines. Consequently, polymorphisms in Vitamin D receptor genes will influence the susceptibility and disease profile following an infection (Peng et al., 2014) Previous studies and meta-analyses have reported contradictions in their findings and few of these studies have integrated cytokine gene promoter polymorphisms and VDR polymorphisms. The aim of this current study is to illuminate on to the role selected host genetic factors in disease evolution and susceptibility to HBV infection. The study focused on seven SNPs; two in the cytokine promoter genes and 2 in the VDR gene polymorphism. The SNPs in the cytokine gene promoter included IL-10-592C/A, IL-10-1082A/G, TNF-a-238G/A, TNF-a-308G/A, and INF- $-1+874 \mathrm{~A} / \mathrm{T}$ while the SNPs in the VDR gene included VDR A/a and VDR T/t. genotypes frequencies were compared between the chronic hepatitis $B$ infected (CHB) and health controls $(\mathrm{HC})$, resolved and asymptomatic carriers (ASC).

Interleukin-10 (IL-10) is a key immune regulatory cytokine which is secreted by mainly T-helper 2 (Th2) cells and T-regulatory cells (Treg) as well as macrophages(L. Gao et al., 2016). IL-10 inhibits the secretion of TNF-a; a Th1 cytokine justifies its immune regulatory role. In our systematic review and metaanalysis, IL-10-592AA was associated with reduced risk of HBV infection as well as increased chances of resolving the infection (Table $2 \&$ Figure 2). This finding is not surprising as it was consistent with an earlier finding by Wang, Huang, Sun, Ma, \& Zhen, (2011) who established the frequency of genotype AA was more frequent in patients with viral clearance. Consistent results have also been reported by Turner, 
William, Sankaran, Lazarus, \& Sinnott, (1997) who established that IL-10-592AA genotype exerts a protective effect against HBV infection. In our study, IL-10-592CC was associated with increased risk of chronic infection (Table 2, Figures, 2-6) reducing the changes of resolving the infection consistent with the findings by Wang et al.,(2012). Thus allele $\mathrm{C}$ mutated to $\mathrm{A}$ provides protection against HBV infection while mutation of allele $A$ to $C$ at the same locus would increase the susceptibility to chronic infection. However, the association of IL-10592CC genotype in our meta-analysis and in other studies (Cheong et al., 2006) lacked statistical significance and more work still needs to be done to confirm this relationship.

When the frequency of IL $-10-1082 \mathrm{~A} / \mathrm{G}$ was evaluated between the $\mathrm{CHB}$ patients and health controls/ resolved, IL-1082AA was associated with increased risk of HBV infection and progressing to chronic disease while the genotypes IL-10-1082 AG was associated with reduced risk of infection (Figure 6, Table 2). Therefore allele A mutated to $\mathrm{G}$ will reduce the risk of $\mathrm{HBV}$ infection and progression while allele $G$ mutated to allele $A$ will increase the risk of infection. Our finding from the meta-analysis was consistent with the earlier findings by Gao et al. 2017 who reported that allele $G$ was protective while allele $A$ shown increased susceptibility. Thu A mutated to $G$ will increase protection against HBV infection and progression to liver cirrhosis while allele $G$ mutated to $A$ increases susceptibility. However the findings of the current meta-analysis contradicted with the findings reported by Moudi et al., (2016) who reported an increased susceptibility to HBV infection in subjects with IL-10-1082AG and GG genotypes.

Tumor Necrosis Factor- alpha (TNF-a) and Interferon gamma (INF- $\gamma$ ) are Th1 cytokines that particulate in host immune response during HBV infection and viral clearance (F. Wang, 2003). TNF-a has five polymorphisms in its promoter region located at the following positions upstream of the transcription initiation site; $-1030 \mathrm{C} / \mathrm{T},-863 \mathrm{C} / \mathrm{A},-857 \mathrm{C} / \mathrm{T},-308 \mathrm{G} / \mathrm{A}$ and $238 \mathrm{G} / \mathrm{A}$. Of these the most implicated in diseases profile and susceptibility to HBV infection are -308G/A and -238G/A (Kruger, Gerken, Schneider, $\& \mathrm{Bu}, 1998)$ and have been reviewed in our systematic review and meta-analysis. In the current study, TNF-a-238 AA+AG was associated with reduced risk of HBV infection and showed an increase in asymptomatic as well as resolved subjects. However, genotype GG was associated with increased risk of chronic infection (Table 2, Figure 9). The finding in our meta-analysis is consistent with the finding reported by (Panigrahi et al., 2014) who reported was significantly high TNF-a-238GG genotype in the cases than the controls and a high TNF- $a$ AA in the controls than the cases. This suggests that allele $A$ mutated into $G$ at the above locus would increase the susceptibility to HBV infection. Studies by (Li et al., 2005) have posted similar findings. Other studies by (Kao et al., 2010) however contradicted our findings and those from other earlier reported studies.

In the present study, the frequency of TNF-a-308G/A among the chronically infected HBV subjects and those who had resolved the virus was investigated in order to come up with constructive clues pertaining its role in HBV clearance. The genotype $G G$ was associated with borderline viral clearance $(O R=0.803)$ while the genotypes $A A+A G$ were associated with a lower risk of infection to chronicity $(O R=1.124)$. This finding is consistent with the finding from a meta-analysis by (Zheng et al., 2010) which reported a lower risk associated with -308 variant genotypes $A A$ and $G A$ as well as a moderate decrease in risk among 
subjects with TNF-a-308GG (Wei, Liu, \& Chen, 2011). However, these findings are contradicted by (Kruger et al., 1998) leaving knowledge gaps justifying the need for more studies.

Interferon gamma has similar effector mechanism as tumour necrosis factor alpha. Polymorphisms in the promoter site of the INF- $\gamma+874 \mathrm{~A} / \mathrm{T}$ gene locus and their association with hepatitis $B$ susceptibility/resistance have been investigated elsewhere and in our meta-analysis. In the current study, the AA + AT were associated with reduced risk of HBV infection $(O R=0.522)$ while genotype AA was only associated with a borderline line protective role $(\mathrm{OR}=0.976)$. The INF- $\gamma+874 \mathrm{~T} / \mathrm{A}$ genotype TT is associated with high expression of the cytokine which is a potent anti-viral cytokine reducing the susceptibility to HBV infection (Sun et al., 2015).In contrast the AA genotype is associated with low cytokine expression increasing the risk of HBV infection consistent with our findings. However, in the current meta-analysis, the AT + TT genotype suggests a reduced risk of HBV infection. This shows that the T-allele is probably dominant over A allele and has more powers of expression such that only individuals with AA genotype are at a risk of HBV infection

In active form, vitamin $D$ is an immune regulatory hormone that activates Th2 cytokines and inhibits Th1 cytokine mediated reactions. Polymorphisms in the genes for vitamin D receptors will affect the expression levels of both Th1 and Th2 cytokines and this will in turn influence the evolution of the disease as well as the susceptibility/resistance to infection. The VDR gene has four polymorphisms that are implicated in several immune mediated diseases including HBV infection (Suneetha et al., 2006). In this meta-analysis VDR Apa1 (A/a) and Taq1(T/t) and their association with disease susceptibility/resistance as well as disease evolution were investigated. We compared the prevalence of these genotypes in the heterozygous state and homozygous state in the health controls and chronically infected subjects in the same population. Our findings reported reduced risk of infection in both homozygous (dominant and recessive) while the heterozygous were associated with mild risk of infection (Table 2). These findings are similar to findings by (Suneetha et al., 2006) who reported association of aa/AA and tt/TT with more severe disease than the heterozygous Aa or Tt.

In conclusion, our meta-analysis of 27 eligible case-control studies indicated that IL-10592AA, and TNF-a $A A+G G$ genotypes significantly associated with reduced risk of hepatitis $B$ infection by the random model. Several other polymorphisms are associated with reduced risk of HBV infection with $\mathrm{OR}<1$ but the results were not statistically significant. It is worth noting that several SNPs were associated with increased risk of HBV infection particularly IL-10-1082AA and TNF-a 238GG with high Odds ratio, though most of the SNPs had borderline risk of HBV infection. Thus more validations are needed to qualify the results of our meta-analysis especially using the African population because there scanty information in literature that has investigated SNPs in the cytokine promoter genes and then VDR gene polymorphisms.

Our meta-analysis could not go without limitations. First, some studies had small sample size hence low statistical power, consequently most of the SNP analyses were indicating association with increased/decreased risk of infection with HBV culminating into chronicity, but lacked statistical

Page $11 / 32$ 
significance. Secondly, most of the studies were from a localized ethnic group and the findings could not be generalized to other population especially the African popukation

However, despite the above limitations, our meta-analysis pooled a reasonable number of cases and controls to raise the statistical power.

\section{Declaration}

The authors declare that they have no conflict of interest

\section{Acknowledgement}

The authors are grateful to the support and guidance from the deanship, Habib Medical School, Islamic University in Uganda, faculty of Health Sciences. We also feel indebted to the Campus Librarian Mr. Musigire Rashid for allowing the authors to access the data bases from which the journal articles were obtained for our meta-analysis.

\section{References}

Baghi, S. G., Alavian, S. M., Mehrnoush, L., \& Salimi, S. (2015). Impact of the IL-10 Promoter Gene Polymorphisms in the Severity of Chronic Hepatitis B Infection, 15(7).

http://doi.org/10.5812/hepatmon.28287v2

Cheong, J., Cho, S., Hwang, I., Yoon, S., Lee, J., Park, C., ... Kim, J. (2006). Association between chronic hepatitis $B$ virus infection and interleukin-10, tumor necrosis factor-a gene promoter polymorphisms. $J$ Gastroenterol Hepatol., 21, 1163-9.

Dondeti, M. F., El-maadawy, E. A., \& Talaat, R. M. (2016). Hepatitis-related hepatocellular carcinoma: Insights into cytokine gene polymorphisms, 22(30), 6800-6816. http://doi.org/10.3748/wjg.v22.i30.6800

Elmer, P., Tuncbilek, S., Aydin, K., \& Hizel, K. (2013). Vitamin D and Tumor Necrosis Factor-Alpha Receptor Gene Polymorphisms in Various Hepatitis B Clinical Conditions in Turkey, 6(5), 185-190.

Falleti, E., Bitetto, D., Fabris, C., Cussigh, A., Fontanini, E., Fornasiere, E., ... Fontanini, E. (2010). Vitamin D receptor gene polymorphisms and hepatocellular carcinoma in alcoholic cirrhosis, 16(24), 3016-3024. http://doi.org/10.3748/wjg.v16.i24.3016

Fletcher, G. J., Samuel, P., Christdas, J., Gnanamony, M., Ismail, A.M., Anantharam, R., ... Abraham, P. (2011). Association of HLA and TNF polymorphisms with the outcome of HBV infection in the South Indian population. Genes and Immunity, 12(7), 552-558. http://doi.org/10.1038/gene.2011.32 
Gao, L., Chen, X., Zhang, L., Wu, D., Zhao, H., \& Niu, J. (2016). Association of IL - 10 polymorphisms with hepatitis B virus infection and outcome in Han population. Eu J Med Res, 1-6.

http://doi.org/10.1186/s40001-016-0218-9

Gao, Q., Xie, J., Wang, L., Zhou, Q., Zhang, S., \& L-m, W. (2017). Interaction effects among IFN-y + 874, ILpolymorphisms on the clinical progression of subjects infected with hepatitis B virus and / or hepatitis $C$ virus: a retrospective nested case-control study, 2,1-7. http://doi.org/10.1136/bmjopen-2016-013279

Ge, D., Fellay, J., Thompson, A., Simon, J., Shianna, K., Urban, T., ... Qiu, P. (2009). Genetic variation in IL28B predicts hepatitis B treatment-induced viral clearance. Nature, 461, 399-401.

Gusatti, C. de S., Costi, C., Rubia, M., Halon, L., Grandi, T., Ferrari, A., ... Rodenbusch, R. (2016). Association between cytokine gene polymorphisms and outcome of hepatitis $B$ virus infection in southern Brazil Association Between Cytokine Gene Polymorphisms and Outcome of Hepatitis B Virus Infection in. Journal of Medical Virology, (March). http://doi.org/10.1002/jmv.24518

Heidari, Z., Moudi, B., Sagheb, H. M., \& Moudi, M. (2016). Association of TNF- a Gene Polymorphisms with Production of Protein and Susceptibility to Chronic Hepatitis B Infection in the South East Iranian Population, 16(11). http://doi.org/10.5812/hepatmon.41984.Research

Kao, P., Wu, J., Ni, Y., Lin, Y., Chen, H., \& Hsu, S. (2010). Tumour necrosis factor-alpha promoter region polymorphisms affect the course of spontaneous HBsAg clearance. Liver International, 30, 1448-1453.

Kim, Y. J., Lee, H., Yoon, J., Kim, C. Y., Park, M. H., Kim, L. H., ... Shin, H. D. (2018). Association of TNF- a promoter polymorphisms with the clearance of hepatitis B virus infection, 12(19), 2541-2546.

http://doi.org/10.1093/hmg/ddg262

Kruger, A., Gerken, G., Schneider, P.M., \& Bu, K. M. Z. U. M. (1998). A tumour necrosis factor-alpha ( TNF- a) promoter polymorphism is associated with chronic hepatitis B infection, 579-582.

Li, H., Li, Z., Liu, Y., Li, J., Dong, J., \& Gao, J. (2005). Association of polymorphism of tumour necrosis factor-alpha gene promoter region with outcome of hepatitis B virus infection. World J Gastroenterol, 11, 5213-5217.

Manjita, S., Arttrika, R., Jitendra, K. C., Manish, K. T., Smita, V., Vinod, K. D., ... Ashok, K. J. (2014). Role of Proinflammatory Cytokines (Interferon Gamma) and Anti Inflammatory Cytokine (Interleukin-10) Gene Polymorphisms in Chronic Hepatitis B Infection: An Indian Scenario. JOURNAL OF INTERFERON \& CYTOKINE RESEARCH, 34(7), 547-551.

Migita, K., Miyazoe, S., Maeda, Y., Daikoku, M., Abiru, S., Ueki, T., ... Eguchi, K. (2005). Cytokine gene polymorphisms in Japanese patients with hepatitis B virus infection-association between TGF- $\mathrm{b} 1$ polymorphisms and hepatocellular carcinoma, 42, 505-510. http://doi.org/10.1016/j.jhep.2004.11.026 
Moudi, B., Heidari, Z., Mahmoudzadeh-sagheb, H., Hashemi, M., Metanat, M., Khosravi, S., \& Farrokh, P. (2016). Association Between IL-10 Gene Promoter Polymorphisms ( -592 A / C, -819 T / C, -1082 A / G) and Susceptibility to HBV Infection in an Iranian Population, 16(2). http://doi.org/10.5812/hepatmon.32427

Ognjanovic, S., Yuan, J., Chaptman, A. K., Fan, Y., \& Yu, M. C. (2009). Genetic polymorphisms in the cytokine genes and risk of hepatocellular carcinoma in low-risk non-Asians of USA, 30(5), 758-762. http://doi.org/10.1093/carcin/bgn286

Panigrahi, R., Sarkar, N., Biswas, A., Pal, A., Saha, D., Singh, S. P., ... Chakravarty, R. (2014). Association of TNF-\&alpha; Promoter Polymorphism with HBV Associated Disease Outcome Among HBV Infected Patients from Orissa, Southern Part of East India. Journal of Clinical and Experimental Hepatology, 4(3), 202-208. http://doi.org/10.1016/j.jceh.2014.08.002

Peng, Q., Yang, S., Lao, X., Li, R., Chen, Z., Wang, J., ... Li, S. (2014). Association of single nucleotide polymorphisms in VDR and DBP genes with HBV-related hepatocellular carcinoma risk in a Chinese population. PLOS ONE, 9(12), 1-17. http://doi.org/10.1371/journal.pone.0116026

Sofian, M., Kalantar, E., Aghakhani, A., Hosseini, S., Eslamifar, A., Farazi, A. A., \& Ramezani, A. (2013). No Correlation Between Interleukin-10 Gene Promoter Polymorphisms and Hepatitis B Virus Infection Outcome, 13(5). http://doi.org/10.5812/hepatmon.8803

Stang, A. (2010). Critical evaluation of the Newcastle-Ottawa scale for the assesment of the quality of non-randomised studies in meta-analysis of genome searches. Genet Epidemiol, 25, 603-605.

Sun, Y., Lu, Y., Li, T., Xie, L., Deng, Y., Li, S., \& Qin, X. (2015). Interferon Gamma + 874T / A Polymorphism Increases the Risk of Hepatitis Virus-Related Diseases: Evidence from a Meta-Analysis, 1-15. http://doi.org/10.1371/journal.pone.0121168

Suneetha, P. V., Sarin, S. K., Goyal, A., Kumar, G. T., Shukla, D. K., \& Hissar, S. (2006). Association between vitamin $D$ receptor, CCR5, TNF- $\alpha$ and TNF- $\beta$ gene polymorphisms and HBV infection and severity of liver disease. Journal of Hepatology, 44(5), 856-863. http://doi.org/10.1016/j.jhep.2006.01.028

Tumer, D., William, D., Sankaran, D., Lazarus, M., \& Sinnott, P. (1997). An investigation of polymorphism in the interleukin-10 gene promoter. Eur J Immunogenet, 24(1), 1-8.

Wang, C., Zhang, X., Zhu, B., Hu, D., Wu, J., Yu, R., \& Zhao, W. (2012). Relationship between tumour necrosis factor-alpha, interleukin-12B and interleukin-10 gene polymorphisms and hepatitis $B$ in Chinese Han haemodialysis patients. Nephrology, 17, 167-174.

Wang, F. (2003). Current status and prospects of studies on human genetic alleles associated with hepatitis B virus infection, 9(4), 641-644. 
Wang, S., Huang, D., Sun, S., Ma, W., \& Zhen, Q. (2011). Interleukin-10 promoter polymorphism predicts initial response of chronic hepatitis B to interferon alfa. Virol J, 8, 28.

Wei, M., Liu, B., \& Chen, X. (2011). Polymorphisms of tumor necrosis factor-alpha and hepatocellular carcinoma risk: a HuGE systematic Review and Meta-analysis. Dig Dis Sci, 56(8), 2227-2236.

Yao, L., Xing, S., Fu, X., Song, H., Wang, Z., Tang, J., \& Zhao, Y. (2015). Association between interleukin-10 gene promoter polymorphisms and susceptibility to liver cirrhosis, 8(December 2014), 11680-11684.

Yao, X., Zeng, H., Zhang, G., Zhou, W., Yan, Q., Dai, L., \& Wang, X. (2013). The Associated Ion between the VDR Gene Polymorphisms and Susceptibility to Hepatocellular Carcinoma and the Clinicopathological Features in Subjects Infected with HBV, 2013.

Zheng, M., Qiu, L., Xin, Y., Pan, H., Shi, K., \& Chen, Y. (2010). Tumour necrosis factor-alpha-308A allele may have protective effect for chronic hepatitis B virus infection in Mongoloid population. Int. J Infect Dis, 14(7), 580-585.

Zintzaras, E., \& JP, L. (2005). Heterogeneity testing in meta-analysis of genome searches. Genet Epidemiol, 28, 123-137.

\section{Tables}


Table 1: Characteristics of eligible studies for meta-analysis

$\begin{array}{llllll}\text { First author, Ethnicity } & \begin{array}{l}\text { genotyping Case Control } \\ \text { Method }\end{array} & & \text { QS Loci } & \text { Number } \\ \text { Year } & & \end{array}$

\begin{tabular}{|c|c|c|c|c|c|c|c|c|}
\hline \multirow{3}{*}{ Baba, M } & \multirow{3}{*}{ Egyptian } & \multirow{3}{*}{ SSP-PCR } & \multirow{3}{*}{$\mathrm{CHB}$} & \multirow{3}{*}{ Healthy } & \multirow{3}{*}{7} & \multirow{3}{*}{$\begin{array}{l}\text { IL-10- } \\
\text { 1082A/G }\end{array}$} & Case & Control \\
\hline & & & & & & & \multirow[t]{2}{*}{118} & \multirow[t]{2}{*}{119} \\
\hline & & & & & & & & \\
\hline \multirow[t]{2}{*}{ Bita M, 2016} & \multirow[t]{2}{*}{ Iranian } & \multirow[t]{2}{*}{ RFLP-PCR } & \multirow[t]{2}{*}{$\mathrm{CHB}$} & \multirow[t]{2}{*}{ Healthy } & \multirow[t]{2}{*}{7} & IL-10-592 & \multirow[t]{2}{*}{221} & \multirow[t]{2}{*}{200} \\
\hline & & & & & & $\mathrm{C} / \mathrm{A}$ & & \\
\hline
\end{tabular}

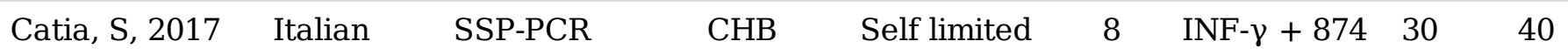

\begin{tabular}{|c|c|c|c|c|c|c|c|c|}
\hline & & & \multicolumn{6}{|c|}{$\mathrm{A} / \mathrm{T}$} \\
\hline $\begin{array}{l}\text { Edmond, F, } \\
2010\end{array}$ & Italian & RFLP-PCR & $\mathrm{LC}$ & Healthy & 7 & VDR A/a & 240 & 236 \\
\hline $\begin{array}{l}\text { Edmond, F, } \\
2010\end{array}$ & Italian & RFLP-PCR & $\mathrm{LC}$ & Healthy & 7 & VDR T/t & 240 & 236 \\
\hline Fletcher, 2011 & Turkey & RFLP-PCR & $\mathrm{CHB}$ & Resolved & 7 & $\begin{array}{l}\text { TNF- } \alpha-238 \\
\text { G/A }\end{array}$ & 137 & 150 \\
\hline Gao, 2016 & Chinese & RFLP-PCR & CHB & Resolved & 7 & $\begin{array}{l}\text { IL-10-592 } \\
\text { C/A }\end{array}$ & 180 & 75 \\
\hline Gao, 2016 & Chinese & RFLP-PCR & $\mathrm{CHB}$ & Resolved & 7 & $\begin{array}{l}\text { IL-10- } \\
\text { 1082A/G }\end{array}$ & 190 & 81 \\
\hline Gusatti, 2016 & Brazil & Mini seq & $\mathrm{CHB}$ & Resolved & 7 & $\begin{array}{l}\text { IL-10-592 } \\
\text { C/A }\end{array}$ & 193 & 147 \\
\hline Gusatti, 2016 & Brazil & Mini seq & $\mathrm{CHB}$ & Resolved & 7 & $\begin{array}{l}\text { IL-10- } \\
1082 \mathrm{~A} / \mathrm{G}\end{array}$ & 196 & 149 \\
\hline Gusatti, 2016 & Brazil & Mini seq & CHB & Resolved & 7 & $\begin{array}{l}\text { TNF- } \alpha-238 \\
\text { G/A }\end{array}$ & 149 & 196 \\
\hline $\begin{array}{l}\text { Hohler, } \mathrm{T} \text {, } \\
1997\end{array}$ & German & Dot Blot & $\mathrm{CHB}$ & Healthy & 8 & $\begin{array}{l}\text { TNF- } \alpha-238 \\
\text { G/A }\end{array}$ & 71 & 90 \\
\hline $\begin{array}{l}\text { Hong-Quan, } \\
2005\end{array}$ & Chinese & RFLP-PCR & $\mathrm{CHB}$ & Self limited & 7 & $\begin{array}{l}\text { TNF- } \alpha-238 \\
\text { G/A }\end{array}$ & 443 & 244 \\
\hline Lanjie, 2015 & Chinese & RFLP-PCR & $\mathrm{CHB}$ & Healthy & 7 & $\begin{array}{l}\text { IL-10-592 } \\
\text { C/A }\end{array}$ & 318 & 318 \\
\hline Lanjie, 2015 & Chinese & RFLP-PCR & $\mathrm{CHB}$ & Healthy & 7 & $\begin{array}{l}\text { IL-10- } \\
1082 \mathrm{~A} / \mathrm{G}\end{array}$ & 318 & 318 \\
\hline $\begin{array}{l}\text { Mangita, S, } \\
2014\end{array}$ & India & RFLP-PCR & $\begin{array}{l}\text { CHB, } \\
\text { LC }\end{array}$ & Healthy & 7 & $\begin{array}{l}\text { INF- } \gamma+874 \\
\text { A/T }\end{array}$ & 232 & 76 \\
\hline Manjita, 2015 & India & RFLP-PCR & $\begin{array}{l}\text { CHB, } \\
\text { LC }\end{array}$ & Healthy & 6 & $\begin{array}{l}\text { IL-10-592 } \\
\text { C/A }\end{array}$ & 232 & 76 \\
\hline
\end{tabular}




\begin{tabular}{|c|c|c|c|c|c|c|c|c|}
\hline Manjita, 2015 & India & SSP-PCR & $\begin{array}{l}\text { CHB, } \\
\text { LC }\end{array}$ & Healthy & 6 & $\begin{array}{l}\text { IL-10- } \\
\text { 1082A/G }\end{array}$ & 232 & 76 \\
\hline $\begin{array}{l}\text { Masoomeh, S, } \\
2013\end{array}$ & Iranian & SSP-PCR & $\mathrm{CHB}$ & $\begin{array}{l}\text { Resolved, } \\
\text { Healthy }\end{array}$ & 7 & $\begin{array}{l}\text { IL-10-592 } \\
\text { C/A }\end{array}$ & 66 & 61 \\
\hline $\begin{array}{l}\text { Masoomeh, S, } \\
2013\end{array}$ & Iranian & SSP-PCR & CHB & Healthy & 6 & $\begin{array}{l}\text { IL-10- } \\
\text { 1082A/G }\end{array}$ & 66 & 61 \\
\hline Migita, 2005 & Asian & SSP-PCR & HCC & No HCC & 6 & $\begin{array}{l}\text { TNF- } \alpha-238 \\
\text { G/A }\end{array}$ & 52 & 184 \\
\hline
\end{tabular}

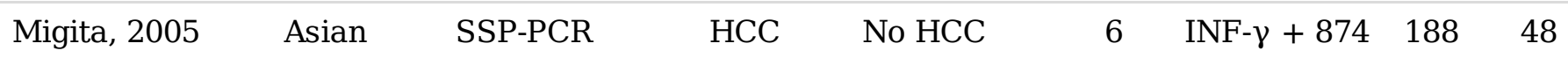

\begin{tabular}{|c|c|c|c|c|c|c|c|c|}
\hline & & & & \multicolumn{5}{|c|}{$\mathrm{A} / \mathrm{T}$} \\
\hline Mita, 2016 & Asian & SS-PCR & $\mathrm{CHB}$ & Healthy & 7 & IL-10- & 221 & 200 \\
\hline & & & & & & $1082 \mathrm{~A} / \mathrm{G}$ & & \\
\hline
\end{tabular}

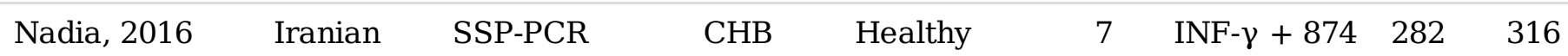

$\begin{array}{lllllllll}\text { Nadia, } 2016 & \text { Iranian } & \text { SSP-PCR } & \text { CHB } & \text { Healthy } & 7 & \text { ANF- } \gamma+874 & 282 & 316 \\ & & & & & \text { A/T } & \\ \text { Pathokamuri, } & \text { India } & \text { RFLP-PCR } & \text { CHB } & \text { Healthy } & 8 & \text { TNF- } \alpha-238 & 214 & 408 \\ 2006 & & & & & \text { G/A } & & \end{array}$

\begin{tabular}{llllllll}
\hline Pathokamuri, India & RFLP-PCR & CHB & Healthy & 8 & VDR A/a & 214 & 408
\end{tabular}
2006

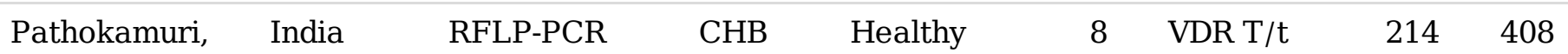
2006

\begin{tabular}{|c|c|c|c|c|c|c|c|c|}
\hline Peng, Q, 2014 & Chinese & RFLP-PCR & $\begin{array}{l}\text { CHB, } \\
\text { HCC }\end{array}$ & Healthy & 7 & VDRC/T & 480 & 180 \\
\hline Peng, Q, 2014 & Chinese & RFLP-PCR & $\begin{array}{l}\text { CHB, } \\
\text { HCC }\end{array}$ & Healthy & 7 & VDRC/G & 480 & 180 \\
\hline Qiu, J, 2009 & Chinese & RFLP-PCR & $\mathrm{CHB}$ & Healthy & 7 & $\begin{array}{l}\text { IL-10-592 } \\
\text { C/A }\end{array}$ & 69 & 74 \\
\hline
\end{tabular}

\begin{tabular}{llllcccc}
\hline Qiu, J, 2009 Chinese & RFLP-PCR & CHB & Healthy & IL-10- & 69 & 74 \\
\end{tabular}

Qiu, J, $2009 \quad$ Chinese $\quad$ RFLP-PCR $\quad$ CHB $\quad$ Healthy $\quad 8 \quad$ INF- $\gamma+874 \quad 69 \quad 74$

\begin{tabular}{|c|c|c|c|c|c|c|c|c|}
\hline & & & & & & $\mathrm{A} / \mathrm{T}$ & & \\
\hline Qiu, J, 2017 & Chinese & RFLP-PCR & $\mathrm{CHB}$ & Healthy & 8 & $\begin{array}{l}\text { IL-10- } \\
\text { 1082A/G }\end{array}$ & 203 & 74 \\
\hline
\end{tabular}

Qiu, J, $2017 \quad$ Chinese $\quad$ RFLP-PCR $\quad$ CHB $\quad$ Healthy $\quad 8 \quad$ INF- $\gamma+874 \quad 203 \quad 74$

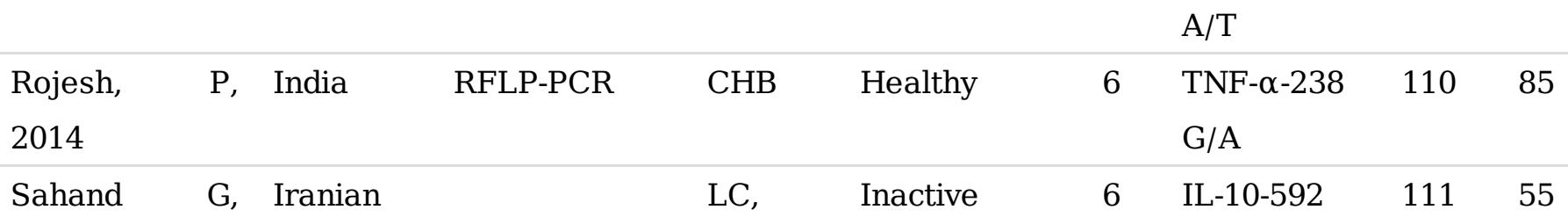




\begin{tabular}{|c|c|c|c|c|c|c|c|c|c|}
\hline 2015 & & & $\mathrm{CHB}$ & carrier & & & $\mathrm{C} / \mathrm{A}$ & & \\
\hline Sahand, 2015 & Iranian & RFLP-PCR & $\mathrm{LC}$ & Inactive & & 6 & IL-10- & 111 & 55 \\
\hline & & & $\mathrm{CHB}$ & carrier & & & $1082 \mathrm{~A} / \mathrm{G}$ & & \\
\hline Semra, T, 2013 & Turkey & ARMS-PCR & $\mathrm{CHB}$, & Healthy & & 7 & VDR A/a & 110 & 56 \\
\hline & & & IC & & & & & & \\
\hline Semra, T, 2013 & Turkey & ARMS-PCR & $\mathrm{CHB}$, & Healthy & & 7 & VDR T/t & 110 & 56 \\
\hline & & & IC & & & & & & \\
\hline Shaoyang, W, & Chinese & RFLP-PCR & $\mathrm{CHB}$ & Healthy & & 6 & IL-10-592 & 52 & 48 \\
\hline 2011 & & & & & & & $\mathrm{C} / \mathrm{A}$ & & \\
\hline Shaoyang, W, & Chinese & RFLP-PCR & $\mathrm{CHB}$ & Healthy & & 6 & IL-10- & 52 & 48 \\
\hline 2011 & & & & & & & $1082 A / G$ & & \\
\hline Simona, 2009 & Hispanic & RT- PCR & $\mathrm{CHB}$ & Healthy & & 8 & IL-10- & 214 & 115 \\
\hline & & & & & & & $1082 A / G$ & & \\
\hline Simona, 2009 & Hispanic & RT-PCR & CHB & Healthy & & 8 & TNF- $\alpha-238$ & 120 & 230 \\
\hline & & & & & & & $\mathrm{G} / \mathrm{A}$ & & \\
\hline Simona, 2009 & USA & qPCR & $\mathrm{CHB}$ & Healthy & & 8 & $I N F-\gamma+874$ & 120 & 230 \\
\hline & & & & & & & $\mathrm{A} / \mathrm{T}$ & & \\
\hline Xing, Y, 2013 & Chinese & RFLP-PCR & $\mathrm{HCC}$ & $\mathrm{HCC}$, & No & 7 & VDR A/a & 436 & 131 \\
\hline & & & & $\mathrm{HBV}$ & & & & & \\
\hline Xing, Y, 2013 & Chinese & RFLP-PCR & HCC & HCC, & No & 7 & VDR T/t & 436 & 131 \\
\hline & & & & $\mathrm{HBV}$ & & & & & \\
\hline Yoon J, 2003 & South & SBE & $\mathrm{CHB}$ & Self limited & & 7 & TNF- $\alpha-238$ & 1,109 & 291 \\
\hline & Korea & & & & & & $\mathrm{G} / \mathrm{A}$ & & \\
\hline Zahra, H, 2016 & Iranian & ARMS-PCR & $\mathrm{CHB}$ & Self limited & & 6 & TNF- $\alpha-238$ & 100 & 40 \\
\hline & & & & & & & $\mathrm{G} / \mathrm{A}$ & & \\
\hline
\end{tabular}


Table 2: General results of the meta-analysis on the cytokine/VDR gene polymorphisms and clinical outcome of HBV infection

\begin{tabular}{|c|c|c|c|c|c|c|c|c|c|}
\hline \multirow{2}{*}{ SNPs } & \multirow[b]{2}{*}{ case/control } & \multirow[b]{2}{*}{ Genotype } & \multirow[b]{2}{*}{ No } & \multirow[b]{2}{*}{ OR (95\%CI) } & \multicolumn{4}{|c|}{ Heterogeneity } & \multirow[t]{2}{*}{ Model } \\
\hline & & & & & $\mathrm{P}$ & $\mathrm{I}^{2}$ & $\mathrm{Q}$ & Phet & \\
\hline \multirow{20}{*}{$\begin{array}{l}\text { IL-10- } \\
\text { 592C/A }\end{array}$} & $\mathrm{CHB} / \mathrm{HC}$ & $\mathrm{AA}$ & 8 & $0.752(0.595$ to & 0.017 & 64.13 & 9.0 & 0.2523 & Random \\
\hline & & & & 0.950 & & & & & \\
\hline & & $\mathrm{AC}$ & 8 & $1.149(0.958$ to & 0.135 & 40.25 & 11.7 & 0.1103 & Fixed \\
\hline & & & & 1.377) & & & & & \\
\hline & & $\mathrm{CC}$ & 8 & $1.306(0.786$ to & 0.303 & 66.59 & 18.0 & 0.0063 & Random \\
\hline & & & & $2.170)$ & & & & & \\
\hline & & $\mathrm{AA}+\mathrm{AC}$ & 8 & 0.787 (0.505 to & 0.292 & 64.34 & 19.6 & 0.0064 & Random \\
\hline & & & & 1.228) & & & & & \\
\hline & CHB/Resolved & $\mathrm{AA}$ & 3 & $0.602(0.372$ to & 0.039 & 38.22 & 3.2 & 0.1982 & Fixed \\
\hline & & & & $0.974)$ & & & & & \\
\hline & & $\mathrm{AC}$ & 3 & $1.155(0.793$ to & 0.453 & 39.86 & 3.3 & 0.1896 & Fixed \\
\hline & & & & 1.683) & & & & & \\
\hline & & $\mathrm{CC}$ & 3 & $1.353(0.850$ to & 0.202 & 0 & 0.2 & 0.9244 & Fixed \\
\hline & & & & $2.154)$ & & & & & \\
\hline & & $\mathrm{AA}+\mathrm{AC}$ & 3 & $1.061(0.566$ to & 0.853 & 53.96 & 4.3 & 0.114 & Random \\
\hline & & & & 1.990) & & & & & \\
\hline & $\mathrm{CHB} / \mathrm{ASC}$ & $\mathrm{CC}$ & 3 & $1.419(0.932$ to & 0.103 & 12.32 & 2.3 & 0.3197 & Fixed \\
\hline & & & & $2.160)$ & & & & & \\
\hline & & $\mathrm{AA}+\mathrm{AC}$ & 3 & $0.705(0.463$ to & 0.103 & 12.32 & 2.3 & 0.3197 & Fixed \\
\hline & & & & 1.073) & & & & & \\
\hline \multirow{6}{*}{$\begin{array}{l}\text { IL-10- } \\
\text { 1082A/G }\end{array}$} & $\mathrm{CHB} / \mathrm{HC}$ & AA & 8 & $1.608(0.861$ to & 0.136 & 84.99 & 46.6 & $<0.0001$ & Random \\
\hline & & & & 3.003) & & & & & \\
\hline & & AG & 8 & $0.485(0.232$ to & 0.054 & 91.27 & 8.2 & $<0.0001$ & Random \\
\hline & & & & 1.014) & & & & & \\
\hline & & GA+GG & 8 & $0.826(0.415$ to & 0.587 & 87.83 & 57.5 & $<0.0001$ & Random \\
\hline & & & & 1.644) & & & & & \\
\hline \multirow{6}{*}{$\begin{array}{l}\text { IL-10- } \\
\text { 1082A/G }\end{array}$} & CHB/Resolved & $\mathrm{GA}+\mathrm{GG}$ & 4 & $0.957(0.693$ to & 0.788 & 0 & 2.5 & 0.4769 & Fixed \\
\hline & & & & 1.320) & & & & & \\
\hline & & $\mathrm{AA}$ & 4 & $1.045(0.757$ to & 0.788 & 0 & 2.5 & 0.4789 & Fixed \\
\hline & & & & 1.442) & & & & & \\
\hline & & AG & 3 & $0.932(0.565$ to & 0.782 & 0 & 1.4 & 0.4877 & Fixed \\
\hline & & & & 1.538) & & & & & \\
\hline \multirow{3}{*}{$\begin{array}{l}\text { TNF- } \\
\alpha-238 \mathrm{G} / \mathrm{A}\end{array}$} & $\mathrm{CHB} / \mathrm{HC}$ & $\mathrm{AA}+\mathrm{AG}$ & 5 & $0.863(0.371$ to & 0.733 & 85.97 & 28.5 & $<0.0001$ & Random \\
\hline & & & & 2.008) & & & & & \\
\hline & & GG & 5 & $0.409(0.140$ to & 0.101 & 93.15 & 58.4 & $<0.0001$ & Random \\
\hline
\end{tabular}


1.189)

\begin{tabular}{|c|c|c|c|c|c|c|c|c|c|c|}
\hline $\begin{array}{l}\text { TNF- } \\
\alpha-238 G / A\end{array}$ & CHB/Resolved & $\mathrm{AA}+\mathrm{AG}$ & 4 & $\begin{array}{l}0.407(0.005 \\
30.1)\end{array}$ & to & $<0.001$ & 98.81 & 251.3 & $<0.0001$ & Random \\
\hline & & GG & 4 & $\begin{array}{l}3.587(0.127 \\
101.176\end{array}$ & to & 0.453 & 98.09 & 157.5 & $<0.0001$ & Random \\
\hline \multirow[t]{2}{*}{$\begin{array}{l}\text { TNF- } \\
\alpha-238 G / A\end{array}$} & $\mathrm{CHB} / \mathrm{ASC}$ & $\mathrm{AA}+\mathrm{AG}$ & 4 & $\begin{array}{l}0.845(0.591 \\
1.208)\end{array}$ & to & 0.356 & 39.13 & 4.9 & 0.1771 & Fixed \\
\hline & & GG & 4 & $\begin{array}{l}1.4(0.591 \\
1.208)\end{array}$ & to & 0.289 & 52.24 & 6.3 & 0.0987 & Random \\
\hline \multirow[t]{2}{*}{$\begin{array}{l}\text { TNF- } \\
\alpha-308 \mathrm{G} / \mathrm{A}\end{array}$} & CHB/Resolved & $\mathrm{AA}+\mathrm{AG}$ & 6 & $\begin{array}{l}1.124(0.725 \\
1.743)\end{array}$ & to & 0.523 & 55.17 & 11.2 & 0.0484 & Random \\
\hline & & GG & 6 & $\begin{array}{l}0.803(0.479 \\
1.36)\end{array}$ & to & 0.405 & 71.26 & 17.4 & 0.038 & Random \\
\hline \multirow[t]{2}{*}{$\begin{array}{l}\text { INF- } \\
\gamma+874 \mathrm{~A} / \mathrm{T}\end{array}$} & $\mathrm{CHB} / \mathrm{HC}$ & $\mathrm{AT}+\mathrm{TT}$ & 6 & $\begin{array}{l}0.522(0.220 \\
1.235)\end{array}$ & to & 0.139 & 91.75 & 60.6 & $<0.0001$ & Random \\
\hline & & $\mathrm{AA}$ & 6 & $\begin{array}{l}0.976(0.491 \\
1.937)\end{array}$ & to & 0.944 & 86.41 & 36.8 & $<0.0001$ & Random \\
\hline \multirow[t]{3}{*}{ VDR A/a } & $\mathrm{CHB} / \mathrm{HC}$ & $\mathrm{AA}$ & 3 & $\begin{array}{l}0.792(0.543 \\
1.156)\end{array}$ & to & 0.227 & 53.01 & 4.3 & 0.119 & Random \\
\hline & & $\mathrm{Aa}$ & 3 & $\begin{array}{l}1.059(0.840 \\
1.33)\end{array}$ & to & 0.628 & 8.4 & 2.2 & 0.3356 & Fixed \\
\hline & & aa & 3 & $\begin{array}{l}0.831(0.452 \\
1.529)\end{array}$ & to & 0.553 & 81.76 & 11.0 & 0.041 & Random \\
\hline \multirow[t]{3}{*}{$\mathrm{VDR} \mathrm{T} / \mathrm{t}$} & $\mathrm{CHB} / \mathrm{HC}$ & $\mathrm{TT}$ & 4 & $\begin{array}{l}0.776(0.813 \\
1.171)\end{array}$ & to & 0.791 & 5.13 & 3.2 & 0.3673 & Fixed \\
\hline & & $\mathrm{Tt}$ & 4 & $\begin{array}{l}1.06 \quad 0.895 \\
1.258)\end{array}$ & to & 0.496 & 0 & 1.8 & 0.6152 & Fixed \\
\hline & & $\mathrm{tt}$ & 3 & $\begin{array}{l}0.976(0.779 \\
1.223)\end{array}$ & to & 0.832 & 0 & 1.1 & 0.5803 & Fixed \\
\hline
\end{tabular}

\section{Figures}



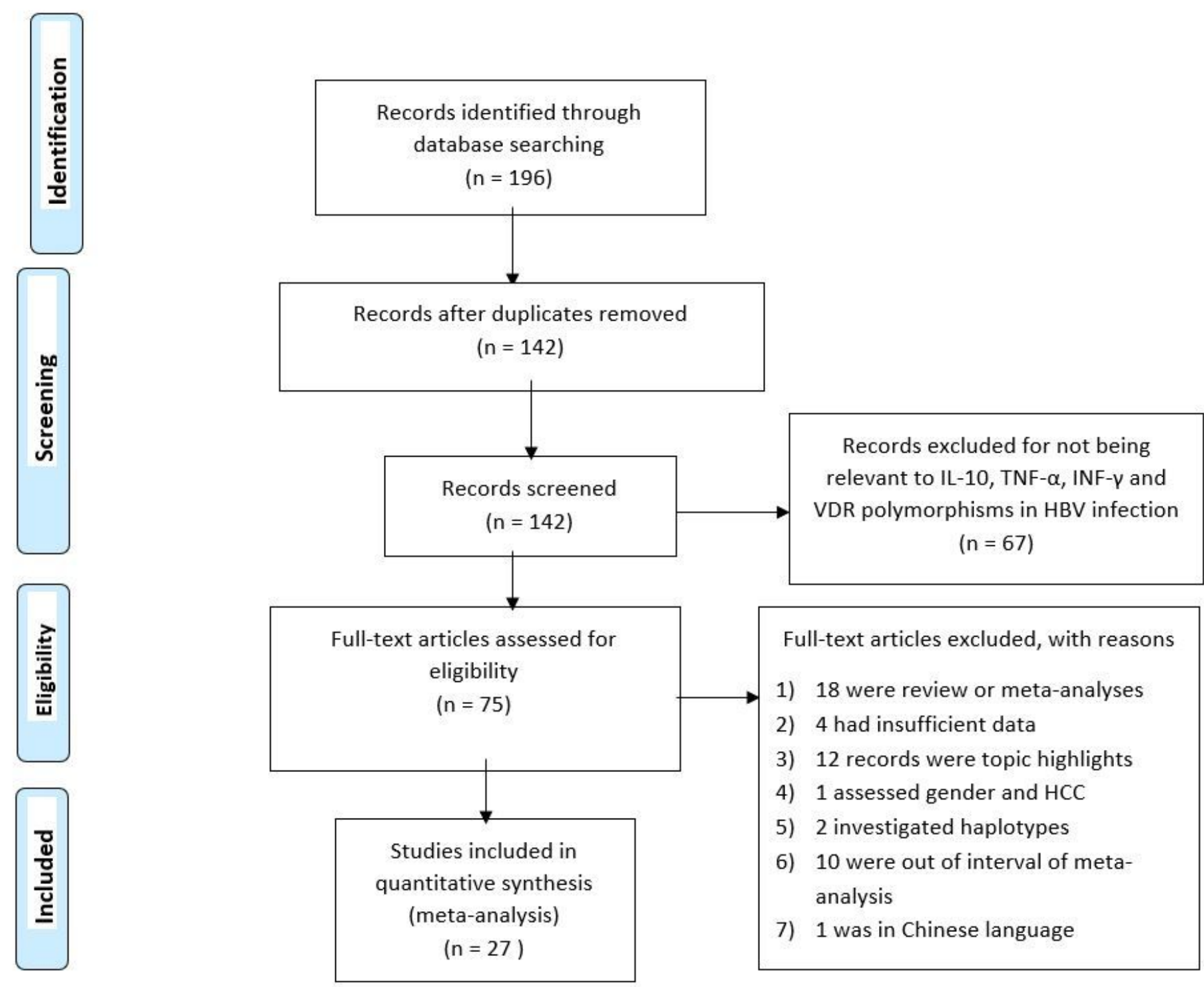

Figure 1

Flow chart for study eligibility following PRISMA criterion In total, 27 full research articles were used in our meta-analysis. The characteristics of the studies are indicated in table 1 below. 


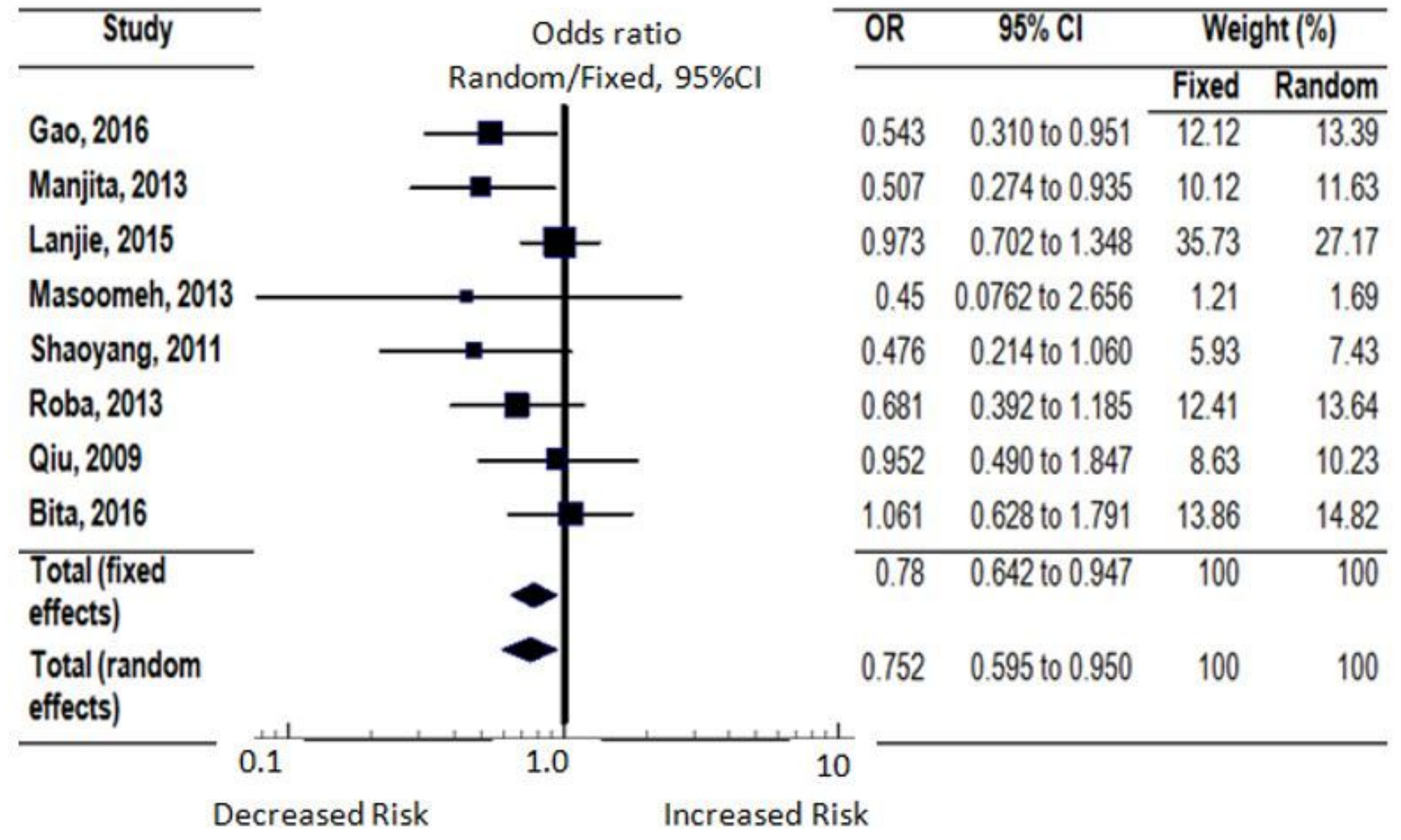

Figure 2

Dominant models IL-10-592 AA on the risk of HBV -HC. The association was indicated as odds ratio (OR) with corresponding $95 \%$ confidence interval. The OR estimate of each study is indicated by the solid black square. The size of the square represents the weight contributed by each study in the meta-analysis. The pooled Odds ratio for both fixed effects and random effects is shown by the diamonds. OR more than 1 indicates increased risk or susceptibility to HBV infection 


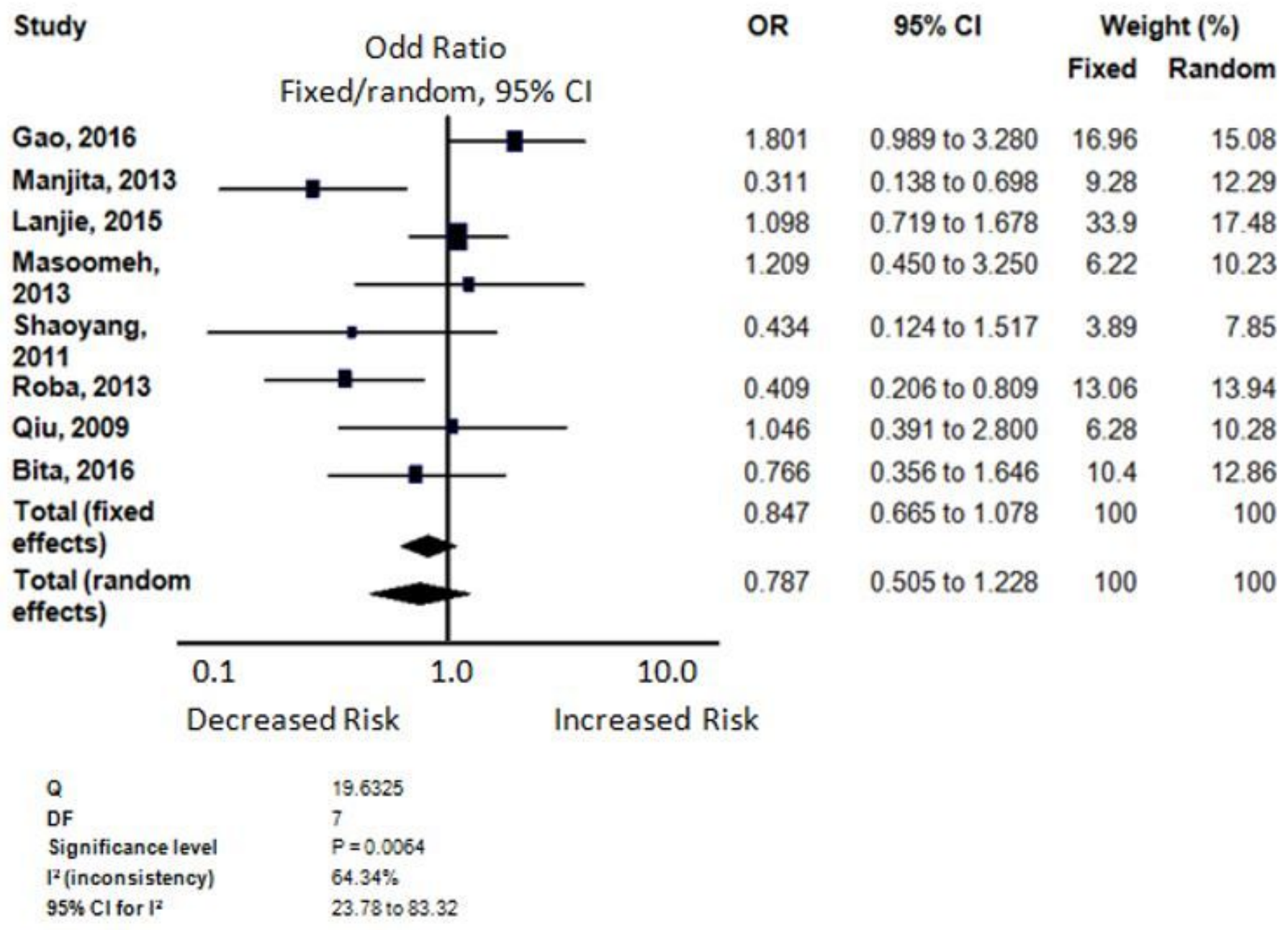

Figure 3

Dominant model IL-10-592 AA+AC on the risk of CHB when compared with health controls. The association was indicated as odds ratio (OR) with corresponding $95 \%$ confidence interval. The OR estimate of each study is indicated by the solid black square. The size of the square represents the weight contributed by each study in the meta-analysis. The pooled Odds ratio for both fixed effects and random effects is shown by the diamonds. OR more than 1 indicates increased risk or susceptibility to HBV infection 
Study

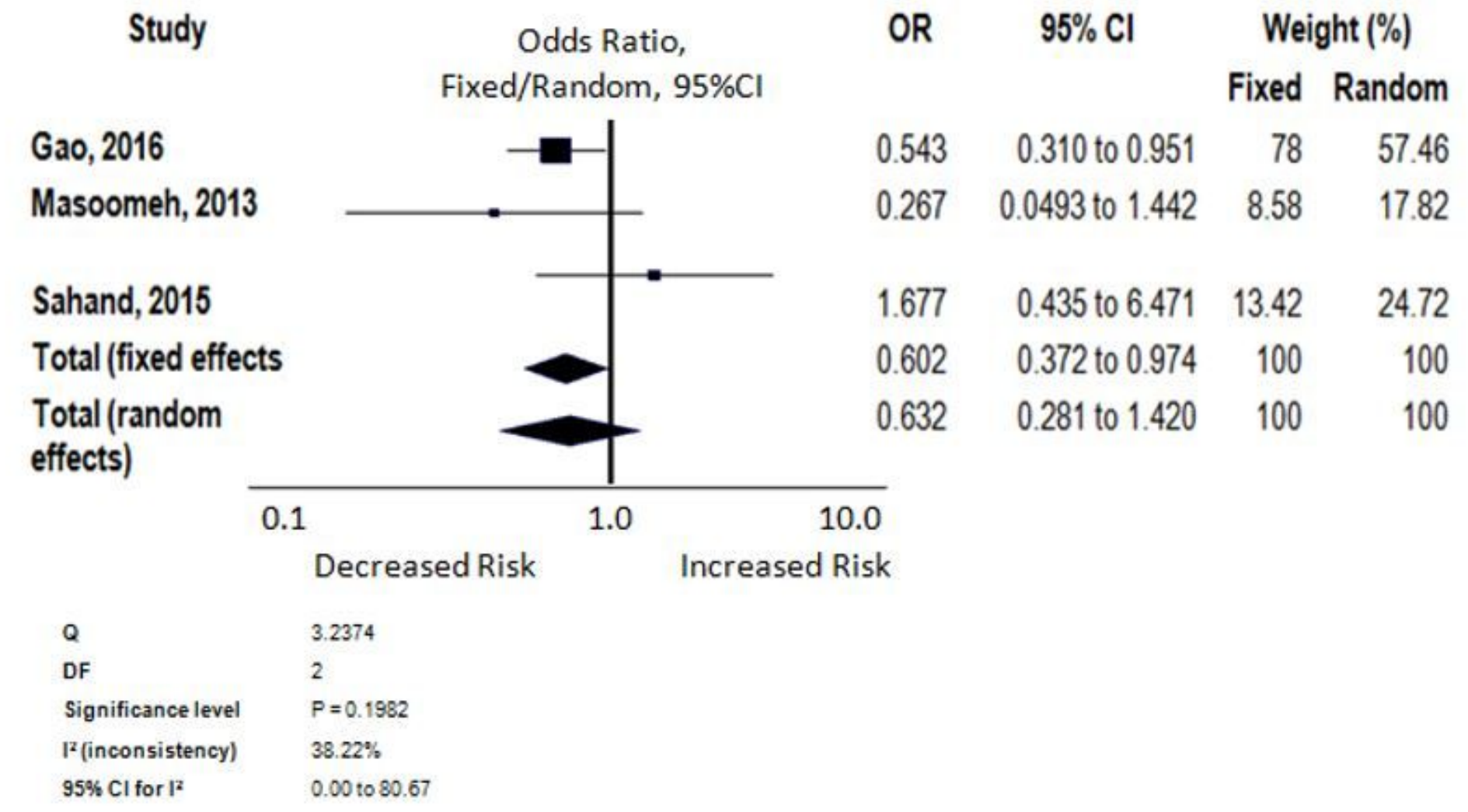

Figure 4

Dominant model IL-10-592 AA on the risk of HBV - self resolved. The association was indicated as odds ratio (OR) with corresponding $95 \%$ confidence interval. The OR estimate of each study is indicated by the solid black square. The size of the square represents the weight contributed by each study in the metaanalysis. The pooled Odds ratio for both fixed effects and random effects is shown by the diamonds. OR more than 1 indicates increased risk or susceptibility to HBV infection 


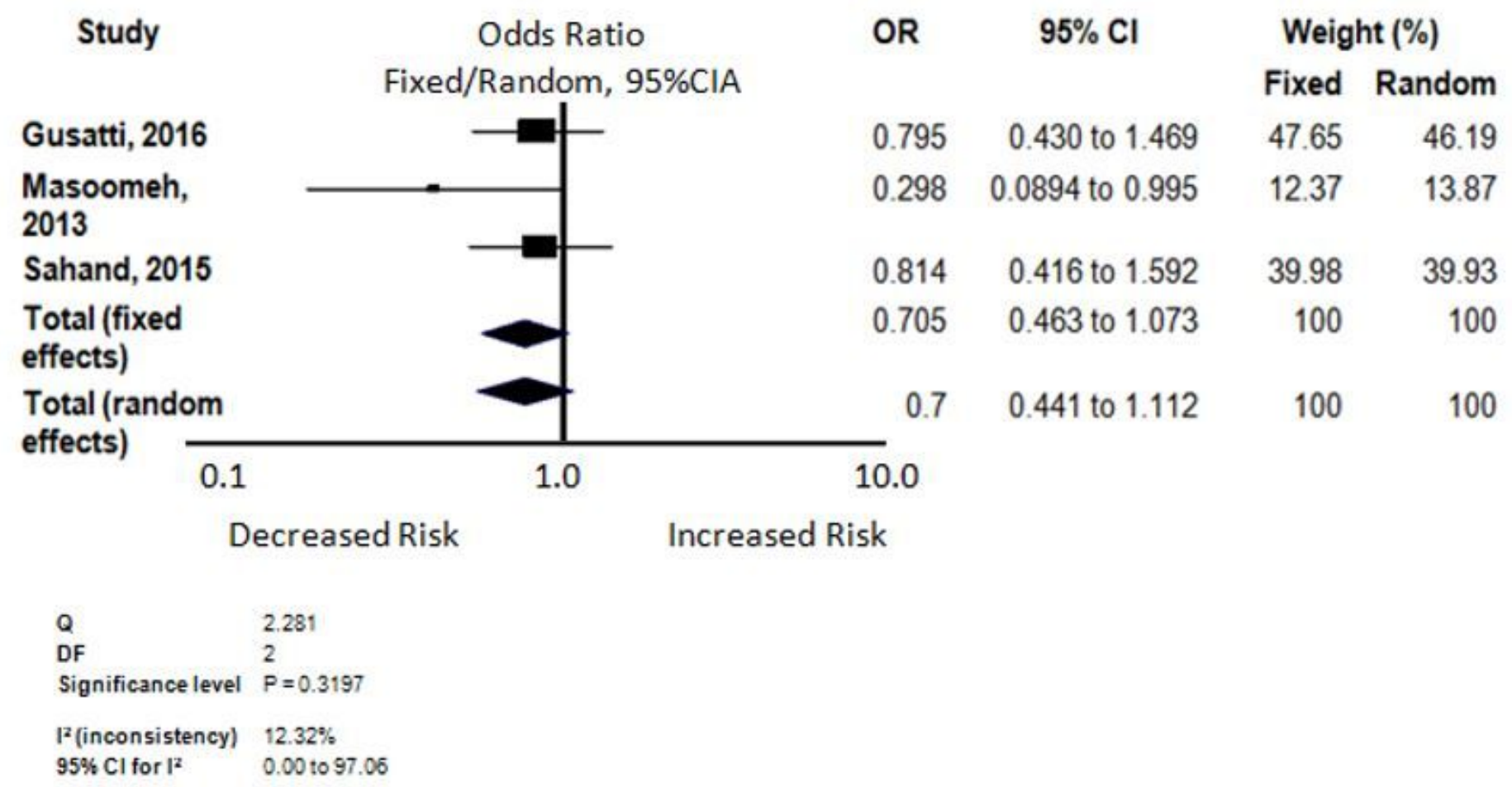

Figure 5

Dominant model IL-10-592 AA +AC on the risk of HBV - ASC. The association was indicated as odds ratio (OR) with corresponding $95 \%$ confidence interval. The OR estimate of each study is indicated by the solid black square. The size of the square represents the weight contributed by each study in the metaanalysis. The pooled Odds ratio for both fixed effects and random effects is shown by the diamonds. OR more than 1 indicates increased risk or susceptibility to HBV infection 


\begin{tabular}{|c|c|c|c|c|c|}
\hline \multirow[t]{2}{*}{ Study } & \multirow[b]{2}{*}{ Odds Ratio, Random/Fixed, $95 \% \mathrm{Cl}$} & \multirow[t]{2}{*}{ OR } & \multirow[t]{2}{*}{$95 \% \mathrm{Cl}$} & \multicolumn{2}{|c|}{ Weight (\%) } \\
\hline & & & & Fixed & Random \\
\hline Gao, 2016 & & 3.89 & 1.803 to 8.395 & 8.54 & 12.67 \\
\hline Manjita, 2013 & & 3.954 & 1.975 to 7.916 & 10.48 & 13.14 \\
\hline Lanjie, 2015 & & 1.81 & 1.126 to 2.910 & 22.38 & 14.39 \\
\hline Masoomeh, 2013 & & 1.077 & 0.397 to 2.923 & 5.07 & 11.2 \\
\hline Shaoyang, 2011 & & 0.8 & 0.170 to 3.774 & 2.1 & 7.97 \\
\hline Gao, 2017 & & 1.412 & 0.686 to 2.905 & 9.7 & 12.97 \\
\hline Qiu, 2009 & & 2.33 & 1.118 to 4.859 & 9.35 & 12.89 \\
\hline Bita, 2016 & & 0.483 & 0.326 to 0.717 & 32.38 & 14.76 \\
\hline Total (fixed effects) & & 1.311 & 1.056 to 1.627 & 100 & 100 \\
\hline $\begin{array}{l}\text { Total (random effects) } \\
\text { Gao, } 2016\end{array}$ & & $\begin{array}{l}1.608 \\
0.236\end{array}$ & $\begin{array}{l}0.861 \text { to } 3.003 \\
0.108 \text { to } 0.517\end{array}$ & $\begin{array}{r}100 \\
6.24\end{array}$ & $\begin{array}{r}100 \\
12.54\end{array}$ \\
\hline $\begin{array}{l}\text { Manjita, } 2013 \\
\text { Lanjie, } 2015\end{array}$ & & $\begin{array}{l}0.13 \\
1.08\end{array}$ & $\begin{array}{r}0.0670 \text { to } 0.254 \\
0.789 \text { to } 1.478\end{array}$ & $\begin{array}{r}8.66 \\
39.06\end{array}$ & $\begin{array}{l}13.06 \\
14.25\end{array}$ \\
\hline Masoomeh, 2013 & $\Longrightarrow$ & 0.941 & 0.350 to 2.531 & 3.93 & 11.58 \\
\hline Shaoyang, 2011 & & 1.25 & 0.265 to 5.897 & 1.6 & 8.88 \\
\hline $\begin{array}{l}\text { Gao, } 2017 \\
\text { Qiu, } 2009\end{array}$ & & $\begin{array}{l}0.126 \\
0.464\end{array}$ & $\begin{array}{r}0.0610 \text { to } 0.258 \\
0.224 \text { to } 0.959\end{array}$ & $\begin{array}{l}7.38 \\
7.29\end{array}$ & $\begin{array}{l}12.83 \\
12.81\end{array}$ \\
\hline Bita, 2016 & $=$ & 1.582 & 1.076 to 2.326 & 25.85 & 14.06 \\
\hline Total (fixed effects) & & 0.704 & 0.584 to 0.848 & 100 & 100 \\
\hline $\begin{array}{l}\text { Total (random effects) } \\
\text { Gao, 2016 }\end{array}$ & & $\begin{array}{l}0.485 \\
0.257\end{array}$ & $\begin{array}{l}0.232 \text { to } 1.014 \\
0.119 \text { to } 0.555\end{array}$ & $\begin{array}{r}100 \\
8.48\end{array}$ & $\begin{array}{r}100 \\
12.68\end{array}$ \\
\hline Manjita, 2013 & & 0.253 & 0.126 to 0.506 & 10.41 & 13.07 \\
\hline Lanjie, 2015 & - & 0.553 & 0.344 to 0.888 & 22.23 & 14.06 \\
\hline Masoomeh, 2013 & - & 0.929 & 0.342 to 2.520 & 5.03 & 11.44 \\
\hline Shaoyang, 2011 & & 1.25 & 0.265 to 5.897 & 2.08 & 8.54 \\
\hline Gao, 2017 & & 3.133 & 1.610 to 6.097 & 11.31 & 13.21 \\
\hline Qiu, 2009 & - & 0.844 & 0.387 to 1.838 & 8.28 & 12.64 \\
\hline Bita, 2016 & $=$ & 2.069 & 1.394 to 3.072 & 32.16 & 14.36 \\
\hline Total (fixed effects) & & 0.951 & 0.768 to 1.177 & 100 & 100 \\
\hline Total (random effects) & & 0.826 & 0.415 to 1.644 & 100 & 100 \\
\hline & 1.0 & & & & \\
\hline
\end{tabular}

Figure 6

Dominant model IL-10-1082 AA, AG and AA + AG on the risk of CHB - health controls . The association was indicated as odds ratio (OR) with corresponding $95 \%$ confidence interval. The OR estimate of each study is indicated by the solid black square. The size of the square represents the weight contributed by each study in the meta-analysis. The pooled Odds ratio for both fixed effects and random effects is shown by the diamonds. OR more than 1 indicates increased risk or susceptibility to HBV infection 


\begin{tabular}{|c|c|c|c|c|c|}
\hline \multirow[t]{2}{*}{ Study } & \multirow{2}{*}{$\begin{array}{l}\text { Odds Ratio } \\
\text { Random/ Fixed, } 95 \% \mathrm{Cl}\end{array}$} & \multirow[t]{2}{*}{ OR } & \multirow[t]{2}{*}{$95 \% \mathrm{Cl}$} & \multicolumn{2}{|c|}{ Weight (\%) } \\
\hline & & & & Fixed & Random \\
\hline Gusatti, 2016 & & 0.97 & 0.625 to 1.495 & 54.74 & 54.74 \\
\hline Masoomeh, 2 & & 0.6 & 0.218 to 1.624 & 10.32 & 10.32 \\
\hline Gao, 2016 & & 1.29 & 0.494 to 3.357 & 11.35 & 11.35 \\
\hline Sahand, 2015 & & 1.46 & 0.750 to 2.834 & 23.58 & 23.58 \\
\hline $\begin{array}{l}\text { Total (fixed } \\
\text { effects) }\end{array}$ & & 1.05 & 0.757 to 1.442 & 100 & 100 \\
\hline $\begin{array}{l}\text { Total (randorr } \\
\text { effects) }\end{array}$ & & 1.05 & 0.758 to 1.445 & 100 & 100 \\
\hline Masoomeh, 2013 & & 1.32 & 0.483 to 3.626 & 25.2 & 25.2 \\
\hline $\begin{array}{l}\text { Gao, } 2016 \\
\text { Sahand, } 2015\end{array}$ & & $\begin{array}{l}1.3 \\
0.7\end{array}$ & $\begin{array}{l}0.406 \text { to } 4.151 \\
0.358 \text { to } 1.385\end{array}$ & $\begin{array}{l}18.93 \\
55.87\end{array}$ & $\begin{array}{l}18.93 \\
55.87\end{array}$ \\
\hline $\begin{array}{l}\text { Total (fixed } \\
\text { effects) }\end{array}$ & & 0.93 & 0.565 to 1.538 & 100 & 100 \\
\hline $\begin{array}{l}\text { Total (random } \\
\text { effects) }\end{array}$ & & 0.93 & 0.559 to 1.537 & 100 & 100 \\
\hline Gusatti, 2016 & & 1.04 & 0.669 to 1.601 & 54.74 & 54.74 \\
\hline Masoomeh, 2013 & & 1.68 & 0.616 to 4.592 & 10.32 & 10.32 \\
\hline Gao, 2016 & & 0.78 & 0.298 to 2.024 & 11.35 & 11.35 \\
\hline Sahand, 2015 & & 0.69 & 0.353 to 1.333 & 23.58 & 23.58 \\
\hline $\begin{array}{l}\text { Total (fixed } \\
\text { effects) }\end{array}$ & & 0.96 & 0.693 to 1.320 & 100 & 100 \\
\hline $\begin{array}{l}\text { Total (random } \\
\text { effects) }\end{array}$ & & 0.96 & 0.692 to 1.320 & 100 & 100 \\
\hline
\end{tabular}

Figure 7

Dominant model IL-10-1082 AA, AG and AA + AG on the risk of HBV - self resolved . The association was indicated as odds ratio (OR) with corresponding $95 \%$ confidence interval. The OR estimate of each study is indicated by the solid black square. The size of the square represents the weight contributed by each study in the meta-analysis. The pooled Odds ratio for both fixed effects and random effects is shown by the diamonds. OR more than 1 indicates increased risk or susceptibility to HBV infection 
TNF- $\alpha-238 G / A:$

\begin{tabular}{|c|c|c|c|c|c|}
\hline \multirow{3}{*}{$\frac{A A+G A}{\text { Study }}$} & \multirow{3}{*}{$\begin{array}{l}\text { Odds Ratio, Fixed/Random, } \\
\qquad 95 \% \mathrm{Cl}\end{array}$} & \multirow{3}{*}{ OR } & \multirow{3}{*}{$95 \% \mathrm{Cl}$} & \multirow{2}{*}{\multicolumn{2}{|c|}{ Weight (\%) }} \\
\hline & & & & & \\
\hline & & & & Fixed & Random \\
\hline Gusatti, 2016 & & 0.73 & $\begin{array}{r}0.387 \text { to } \\
1.376\end{array}$ & 21.21 & 21.46 \\
\hline Hohler, 1997 & & 4.464 & $\begin{array}{r}1.750 \text { to } \\
11.383\end{array}$ & 9.72 & 18.77 \\
\hline Seiji, 2002 & & 0.975 & $\begin{array}{r}0.265 \text { to } \\
3.589\end{array}$ & 5.02 & 15.43 \\
\hline Rajesh, 2014 & & 0.699 & $\begin{array}{r}0.372 \text { to } \\
1312\end{array}$ & 21.45 & 21.49 \\
\hline Pathokamuril 2006 & & 0.295 & $\begin{array}{r}0.188 \text { to } \\
0.461\end{array}$ & 42.6 & 22.85 \\
\hline Total (fixed effects) & & 0.589 & $\begin{array}{r}0.448 \text { to } \\
0.774\end{array}$ & 100 & 100 \\
\hline $\begin{array}{l}\text { Total (random } \\
\text { effects) }\end{array}$ & & 0.863 & $\begin{array}{r}0.371 \text { to } \\
2.008\end{array}$ & 100 & 100 \\
\hline $\begin{array}{l}\text { TNF- } \alpha-238 G / A: G G \\
\text { Gusatti, } 2016\end{array}$ & & 0.103 & $\begin{array}{r}0.0601 \text { to } \\
0.176\end{array}$ & 21.66 & 21.21 \\
\hline Hohler, 1997 & & 0.224 & $\begin{array}{r}0.0878 \text { to } \\
0.571\end{array}$ & 7.14 & 19.12 \\
\hline Seiji, 2002 & & 1.026 & $\begin{array}{r}0.279 \text { to } \\
3.775\end{array}$ & 3.68 & 16.81 \\
\hline Rajesh, 2014 & & 0.466 & $\begin{array}{r}0.258 \text { to } \\
0.840\end{array}$ & 17.96 & 20.98 \\
\hline Pathokamuri, 2006 & & 1.146 & $\begin{array}{r}0.803 \text { to } \\
1.635\end{array}$ & 49.55 & 21.87 \\
\hline Total (fixed effects) & & 0.485 & $\begin{array}{r}0.384 \text { to } \\
0.611\end{array}$ & 100 & 100 \\
\hline $\begin{array}{l}\text { Total (random } \\
\text { effects) }\end{array}$ & & 0.409 & $\begin{array}{r}0.140 \text { to } \\
1.189\end{array}$ & 100 & 100 \\
\hline
\end{tabular}

\section{Figure 8}

Dominant model TNF-a-238 AA+GG and GG on the risk of HBV compared to the Health controls. The association was indicated as odds ratio (OR) with corresponding $95 \%$ confidence interval. The OR estimate of each study is indicated by the solid black square. The size of the square represents the weight contributed by each study in the meta-analysis. The pooled Odds ratio for both fixed effects and random effects is shown by the diamonds. OR more than 1 indicates increased risk or susceptibility to HBV infection 


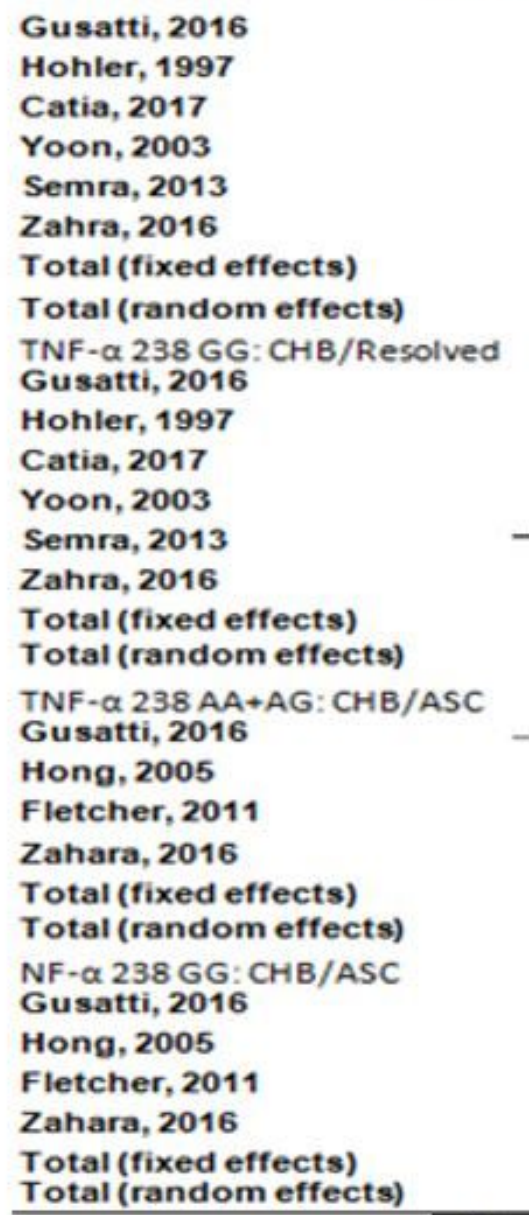

0.1

Decreased Risk
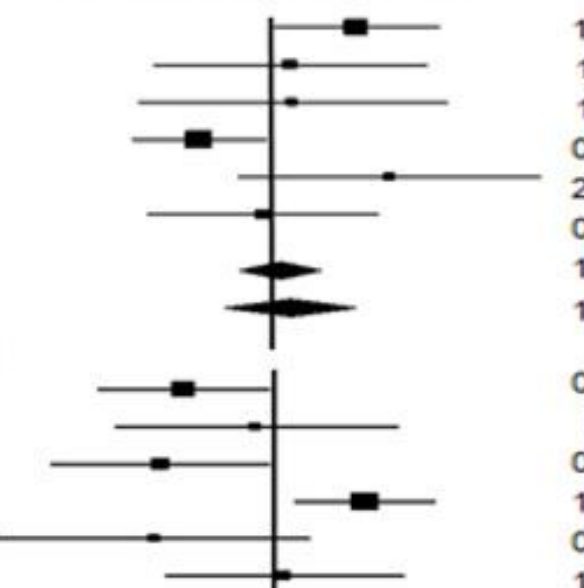

0.561

0.89

0.484

1.794

0.462

1.067

0.885

0.803

0.20 .0452 to 0.885

$0.841 \quad 0.490$ to 1.443

1.17

1.072

0.845

0.839

0.655 to 2.090

0.270 to 4.266

0.591 to 1.208

0.492 to 1.431

1.130 to 22.127

0.965 to 2.963

0.478 to 1.527

0.234 to 3.709

0.948 to 1.967 0.751 to 2.608
Weight $(\%)$
Fixed Random

24.84

21.51

9.16

13.74

7.12

11.81

38.64

7.51

12.73

100

100

24.38

12.2

16.36

100

100

$23.25 \quad 19.26$

$8.54 \quad 14.1$

$14.32 \quad 17.01$

$35.05 \quad 20.74$

$6.99 \quad 12.9$

$11.85 \quad 16$

$100 \quad 100$

$100 \quad 100$

$6.13 \quad 10.79$

$46.52 \quad 39.68$

$40.24 \quad 37.32$

$7.11 \quad 12.21$

$100 \quad 100$

$100 \quad 100$

$6.34 \quad 13.09$

$44.63 \quad 36.53$

$41.67 \quad 35.78$

$7.36 \quad 14.6$

$100 \quad 100$

$100 \quad 100$

$\begin{array}{llll}1.4 & 0.751 \text { to } 2.608 & 100 & 100\end{array}$

\section{Figure 9}

Dominant model TNF-a-238 AA+GG and GG on the risk of HBV compared to the asymptomatic and self resolved. The association was indicated as odds ratio (OR) with corresponding $95 \%$ confidence interval. The OR estimate of each study is indicated by the solid black square. The size of the square represents the weight contributed by each study in the meta-analysis. The pooled Odds ratio for both fixed effects and random effects is shown by the diamonds. OR more than 1 indicates increased risk or susceptibility to HBV infection 
VDR, genotype

AA

Study

Pathokamuri, 2006

Semra, 2013

Falleti, 2010

Total (fixed effects)

Total (random effects)

VDR, genotype Aa

Pathokamuri, 2006

Semra, 2013

Falleti, 2010

Total (fixed effects)

Total (random effects)

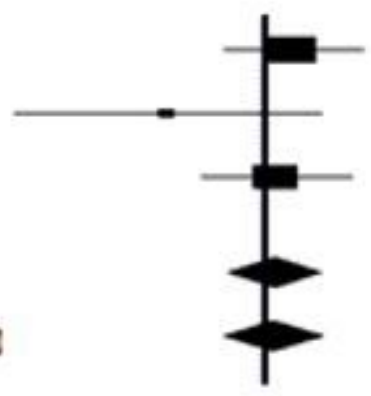

VDR, genotype aa

Pathokamuri, 2006

Semra, 2013

Falleti, 2010

Total (fixed effects)

Total (random effects)

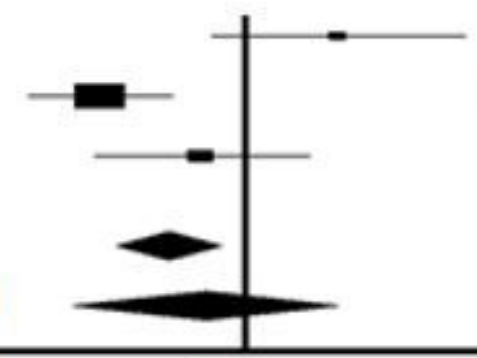

1.170 .837 to 1.626

0.630 .302 to 1.327

48.6

9.81

$\begin{array}{llll}1.07 & 0.746 \text { to } 1.532 & 41.6 & 41.55\end{array}$

$\begin{array}{llll}1.06 & 0.840 \text { to } 1.334 & 100 & 100\end{array}$

$\begin{array}{llll}1.05 & 0.823 \text { to } 1.348 \quad 100 \quad 100\end{array}$

47.69

10.76

41.55

100

100

0.1

1.0

10.0

Decreased Risk Increased Risk

Figure 10

Dominant and recessive model of VDR A/a, genotypes AA, Aa and aa on the risk of HBV compared to the self controls. The association was indicated as odds ratio (OR) with corresponding $95 \%$ confidence interval. The OR estimate of each study is indicated by the solid black square. The size of the square represents the weight contributed by each study in the meta-analysis. The pooled Odds ratio for both fixed effects and random effects is shown by the diamonds. OR more than 1 indicates increased risk or susceptibility to HBV infection 


\begin{tabular}{|c|c|c|c|c|c|}
\hline Study & \multirow{2}{*}{$\begin{array}{c}\text { Odds Ratio, } \\
\text { Fixed/Random, } 95 \% \mathrm{Cl}\end{array}$} & \multirow[t]{2}{*}{ OR } & \multirow[t]{2}{*}{$95 \% \mathrm{Cl}$} & \multicolumn{2}{|c|}{ Weight (\%) } \\
\hline & & & & Fixed & Random \\
\hline Pathokamuri, 2006 & Fixed/Random, 95\% & 0.99 & 0.711 to 1.386 & 30 & 30.07 \\
\hline Xing, 2013 & & 1.03 & 0.774 to 1.378 & 40.2 & 39.39 \\
\hline Falleti, 2010 & & 0.77 & 0.524 to 1.118 & 23.3 & 23.72 \\
\hline Semra, 2013 & & 1.51 & 0.736 to 3.107 & 6.45 & 6.81 \\
\hline Total (fixed effects) & & 0.98 & 0.813 to 1.171 & 100 & 100 \\
\hline $\begin{array}{l}\text { Total (random } \\
\text { effects) }\end{array}$ & & 0.98 & 0.807 to 1.179 & 100 & 100 \\
\hline VDR.genotype Tt & & & & & \\
\hline Pathokamuri, 2006 & & 0.92 & 0.663 to 1.289 & 26.4 & 26.39 \\
\hline Xing, 2013 & & 1.05 & 0.816 to 1.355 & 45.4 & 45.35 \\
\hline Falleti, 2010 & & 1.29 & 0.898 to 1.846 & 22.5 & 22,46 \\
\hline Semra, 2013 & & 1.01 & 0.496 to 2.046 & 5.8 & 5.8 \\
\hline Total (fixed effects) & & 1.06 & 0.895 to 1.258 & 100 & 100 \\
\hline $\begin{array}{l}\text { Total (random } \\
\text { effects) }\end{array}$ & & 1.06 & 0.895 to 1.259 & 100 & 100 \\
\hline VDRgenotype tt & & & & & \\
\hline Pathokamuri, 2006 & & 1.25 & 0.735 to 2.130 & 18 & 18 \\
\hline Xing, 2013 & & 0.91 & 0.679 to 1.211 & 60.8 & 60.83 \\
\hline Falleti, 2010 & & 0.98 & 0.600 to 1.601 & 21.2 & 21.17 \\
\hline Total (fixed effects) & & 0.98 & 0.779 to 1.223 & 100 & 100 \\
\hline $\begin{array}{l}\text { Total (random } \\
\text { effects) }\end{array}$ & & 0.98 & 0.780 to 1.224 & 100 & 100 \\
\hline U. & 0 & & & & \\
\hline
\end{tabular}

Figure 11

Dominant and recessive model of VDR T/t , genotypes TT, Tt and tt on the risk of HBV compared to the self controls. The association was indicated as odds ratio (OR) with corresponding $95 \%$ confidence interval. The OR estimate of each study is indicated by the solid black square. The size of the square represents the weight contributed by each study in the meta-analysis. The pooled Odds ratio for both fixed effects and random effects is shown by the diamonds. OR more than 1 indicates increased risk or susceptibility to HBV infection 


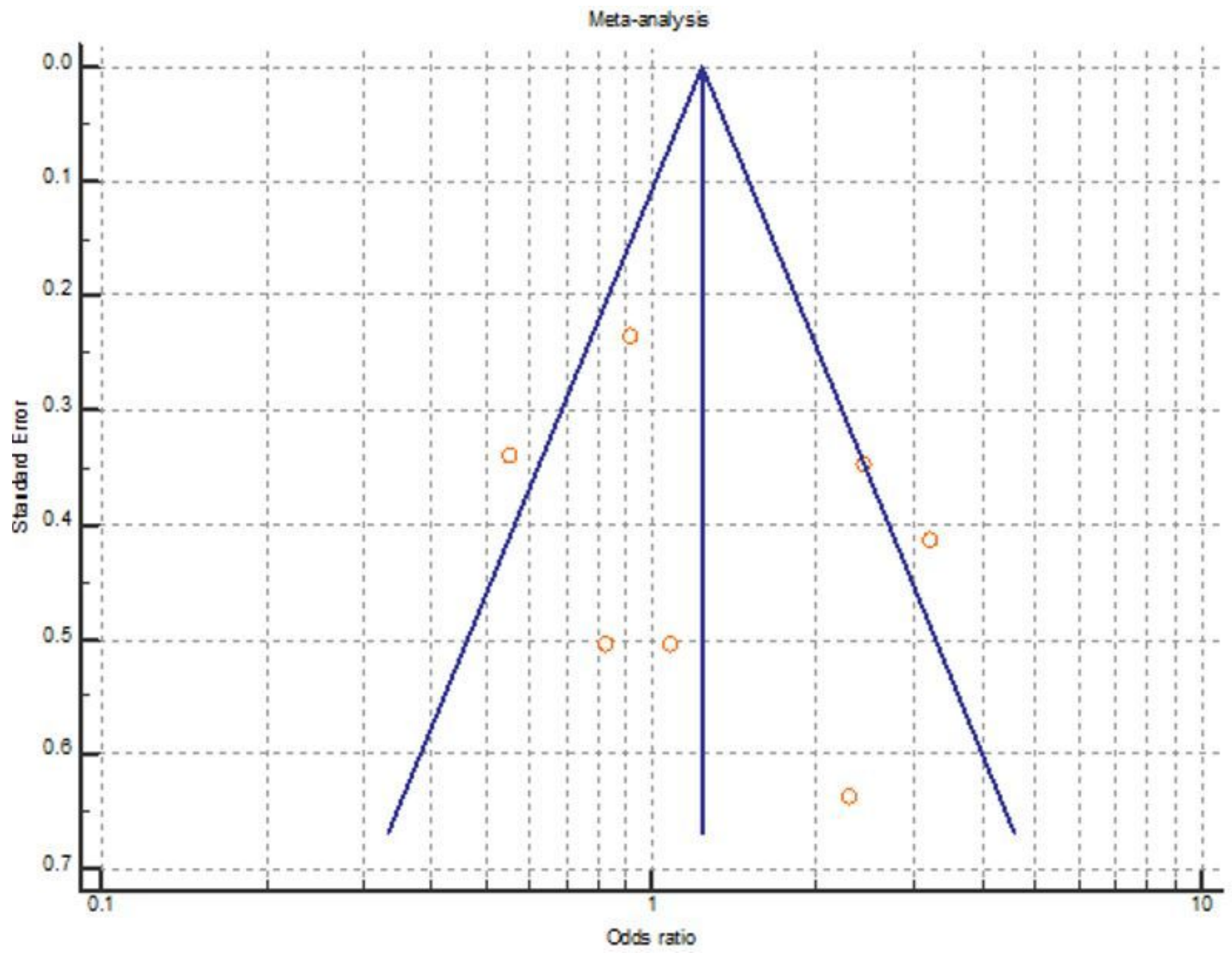

Figure 12

Begg's funnel plot for publication bias

\section{Supplementary Files}

This is a list of supplementary files associated with this preprint. Click to download.

- PRISMAChecklist.docx 